\title{
Stratejik İş Birliği ve Askerî Danışmanlık Kapsaminda Osmanlı Donanmasinda Amiral Limpus Misyonu (1912-1914)
}

\author{
The Admiral Limpus Mission to the Ottoman Navy \\ within the Context of Strategic Cooperation \\ and Naval Consultancy (1912-1914)
}

\author{
Dilara DAL ${ }^{*}$
}

$\ddot{O} z$

$\mathrm{Bu}$ çalsşmada II. Meşrutiyet'in ilan edilmesiyle birlikte donanmantn reorganizasyonu için Osmanl Hükümeti hizmetine alnan son İngiliz danısman olan Amiral Arthur Henry Limpus'un hizmet dönemi ele alnmıstrr. İngiliz Bahriye Nazrm Winston Churchill tarafindan bu görev için bizzat seçilen Amiral Limpus'un göreve alınş süreci, selefleri Amiral Gamble ve Amiral Williams'la yaptiğ görü̈smeler dikkate alnarak incelenmis ve İngiliz subaylarn Osmanh bahriyesinde yetki alanı hususunda yaşadiklar problemler değerlendirilmistir. Amiral Limpus'un Bahriye Nezareti'ne arz ettiği raporlar analiz edilerek, Osmanl bahriye politikasin Avusturya donanmasina denk ve Yunanistan donanmasindan daha güçlü bir filo oluşturmak olarak belirlediği saptanmıştr. Amiral, bu amaçla sattn alnan dretnotlarn İngiltere'deki inşa sürecini yakından takip etmiş, Osmanl bahriye teşkilat yapisinin yeniden düzenlenmesini sağlamıs ve subay ve askerlerin eğitimi için çeşitli alanlarda kurslar organize etmiştir. Bu süreçler İngiliz Ulusal Denizcilik Müzesi Arşivi'nde muhafaza edilen ve ilk kez bu çalssmada kullamlan Amiral Limpus'un kendisine ait eərakı ve Başbakanlik Osmanlh Arşivi belgeleri temel kaynak alnarak analiz edilmiştir.

Anahtar Kelimeler: Amiral Arthur Limpus, Osmanh Imparatorluğu, İngiltere, Bahriye Nezareti, Donanma.

* Dr., İstanbul Üniversitesi, Edebiyat Fakültesi, Tarih Bölümü, Yakınçă̆ Tarihi Anabilim Dalı, İstanbul, Türkiye, ORCID: 0000-0003-3912-0731, e-posta: dilaradal@istanbul.edu.tr.

$\mathrm{Bu}$ çalışmanın önemli bir bölümü Türkiye Bilimsel ve Teknolojik Araştırma Kurumu (TÜBİTAK), Bilim İnsanı Destekleme Daire Başkanlığı tarafından verilen 2219-Yurt Dış1 Doktora Sonrası Araştırma Bursu ile gerçekleştirilmiştir (Araştırma Proje No. 1059B191800794).

Geliş Tarihi / Submitted: 02.02.2021

Kabul Tarihi / Accepted: 04.06.2021 


\section{Abstract}

This study examines the period of the service of Arthur Limpus, the last British Admiral who entered the service of the Ottoman Government on 25 May 1912 for the reorganization of the Ottoman navy. The assignment process of Admiral Limpus, who was personally selected by the First Lord of the Admiralty Winston Churchill for this duty, was analyzed by scrutinizing the correspondence he exchanged with his predecessors Admiral Gamble and Admiral Williams, and the problems that the British officers encountered concerning their scope of authority in the Ottoman navy were evaluated. By analyzing the reports submitted by Admiral Limpus to the Ottoman Ministry of Nary, it was understood that the Ottoman naval policy was determined as creating a fleet equal to the Austrian navy and stronger than the Greek navy. For this purpose, the Admiral closely followed the dreadnoughts, which were under construction in Britain, ensured the reorganization of the structure of the Ministry of Navy, and organized courses in various fields for the training of officers and soldiers. These processes have been analyzed based on Admiral Limpus' private documents, which are kept in the Caird Archive of the British National Maritime Museum and used for the first time in this study, and the documents of the Prime Ministerial Ottoman Archive.

Keywords: Admiral Arthur Limpus, Ottoman Empire, Britain, Ministry of Nary, Nary.

\section{Giriş}

23 Temmuz 1908'de ilan edilen II. Meşrutiyet'le birlikte bahriye dairesinin reorganizasyonu için İngiltere'ye başvurulmuş ve Cihan Harbi'nin başlangıcına dek üç İngiliz danışma heyeti Osmanlı donanmasında hizmete alınmıştır. Bab-1 Ali'nin bu kararı almasında filonun ve tersanelerin içinde bulundukları durum etkili olmuştur. ${ }^{1}$ II. Meşrutiyet'in ilan edildiği

\footnotetext{
1 1908'de İngiliz Deniz İstihbaratı'nın Tersane-i Amire hususunda hazırladığı bir rapor bu durumu gözler önüne sermektedir. Buna göre; Tersane-i Amire'deki makine ve fabrikalar ihmal ve kullanılmama sebebiyle işe yaramaz durumdaydı. 1906'daki başka bir raporda Tersane-i Amire'de ve Tophane-i Amire'de toplam 700 kişinin çalıștığı bildirilmişti. Buna karşın herhangi bir çalışma gözlemlenmediği gibi Tersane-i Amire'deki inşaat faaliyetleri durdurulmuş vaziyetteydi. Mevcut dört adet havuzdan (Azap Kapı, Orta Avlu, Kasım Paşa ve Yüzer Havuz) yüzer havuz, 1906'da palamar yerinden batmış durumdaydı ve diğer havuzlar çeşitli aşamalarda çürümekte olan eski vapur, gambot, duba, mavna vs. tarafından işgal edilmişti. Her bir havuz, en az iki-üç adet bu cins malzeme ile kaplıydı. Havuzları kuru tutmak ve suyu boşaltmak için iki ila yedi gün gerekiyordu ve bütün havuzlar kötü bir biçimde su sızdırıyordu. Bütün cinslerde en iyi İngiliz firmalarında yapılmış makineler (torna tezgâhları, buharlı çekiçler, çubuk, köşebent, yassı ve sac demir üretimi için hadde makineleri, demir
} 
Stratejik İş Birliği ve Askerî Danışmanlık Kapsamında

Osmanlı Donanmasinda Amiral Limpus Misyonu (1912-1914)

yıl Osmanlı donanmasında 16 zıhlı savaş gemisi, 4 kruvazör, 7 korvet, 26 gambot, 4 torpido kruvazörü, 6 muhrip, 30'u birinci sınıf, 6'sı ikinci sinıf ve 1'i üçüncü sinıf olmak üzere toplam 37 torpidobot ve 2 denizalt1 bulunuyordu. ${ }^{2}$ Bununla birlikte aktif hizmete uygun ve denize elverişli olarak kabul edilebilecek gemiler; Mesudiye, Asar-ı Tevfik, Feth-i Bülend, Avnillah, Muin-i Zafer (zırhlı); Mecidiye, Hamidiye (ikinci sınıf korumalı kruvazör); Peleng-i Derya, Berk-i Satvet, Peyk-i Şevket (torpido kruvazörü); Akhisar, Alpagot, Hamidabad, Sultanhisar, Demirhisar, Sivrihisar, Ankara, Urfa, Antalya, Tokat, Draç, Kütahya, Musul (birinci sinıf torpidobot) olarak sıralanmıştı ve mürettebatları yetersizdi. Denizaltılar, bahri açıdan tamamen işe yaramaz durumdaydı ve Osmanlı donanmasında bulunan hiçbir gemi telsiz telgraf sistemiyle donatılmamıştı. ${ }^{3}$

25 Ağustos 1908'de Osmanlı Bahriyesi'nin yeni bir danışma heyetine olan ihtiyacı, Ferik Mehmet Paşa başkanlığında toplanan Bahriye

levhaların haddesi için demirhaneler, kesme ve delme makineleri, planya, oyma makineleri, 750 ton kapasiteli hidrolik pres ve ahşap bölümünde buhar testeresi ve torna tezgâhı) mevcuttu ancak atıl durumdaydı. Kazancı mağazası geniş olmasına rağmen buradaki her şey öylesine şok edici bir pislik ve bakımsızlık durumuna getirilmişti ki bir iş yapılabilmesi için büyük miktarda para harcanması gerekiyordu (TNA, ADM, 231-49 (1908).

2 1908'de İngiliz Deniz İstihbaratı'nın Osmanlı donanması hususunda hazırladığ rapora göre donanmayı oluşturan gemiler şu şekilde sıralanmaktaydı: Zırhlı Gemiler: Aziziye, Mahmudiye, Osmaniye, Orhaniye, Asar-ı Tevfik, Hifzurrahman, Avnillah, Muin-i Zafer, Asar-ı Şevket, Necm-i Şevket, Íclaliye, Feth-i Bülend, Mukaddeme-i Hayr, Mesudiye, Hamidiye, Hizber; 2. Sınıf Korumalı Kruvazörler: Mecidiye, Hamidiye; 3. Sinıf Korumasız Kruvazörler: Heybetnüma, Lütf-i Hümayun; Korvetler: Beyrut, Iskenderiye, Utarit, Muzaffer, Mansure, Kilid Bahir, Zuhaf; Gambotlar: Akka, Necm-i Feshan, Musul, Seyyar, Müjderesan, Ziver-i Derya, Aynalıkavak, Yalkö̈skü, Şat, Seyyad-ı Derya, Şevketnüma, Sahir, Galata, Kozlu, Nurü’-Bahir, Barika-i Zafer, Nasr-ü Hüda, Keshaf, Seyyah, Saik-i Şadi, Marmaris, Ayntab, Malatya, Bafra, Seddülbahir, Ordu; Torpido Kruvazörleri: Şahin-i Derya, Peleng-i Derya, Berk-i Satvet, Peyk-i Şevket; Muhripler: Tayyar, Berkefsan, Samsun, Bafra, Yarhisar, Taşoz; 1. Sinıf Torpidobotlar: Gilyom, Saiki, Tir-i Zafer, Seyf-i Bahri, Vesile-i Nusret, Satvet, Mahabet, Nasir, Fatih, Nusret, Sahab, Tark, Pervin, Tahir, Ejder, Akhisar, Alpagot, Yunus, Abdülmecid, Ankara, Urfa, Antalya, Tokat, Draç, Kütahya, Musul, Hamidabad, Sultanhisar, Demirhisar, Siorihisar; 2. Sinıf Torpidobotlar: Burhaneddin, Tevfik, Mecidiye, Asar-ı Terakki, Şanaver, Nimet; 3. Sinıf Torpidobotlar: Timsah; Denizaltılar: Abdülmecid, Abdülhamid; Okul Gemileri: Mehmed Selim (torpido okulu), Fethiye; Nakliye Gemileri: Babil, Cidde, Mukaddeme-i Şeref, İzmir, Tir-i Müjgân, Halep, Cam, Bezm-i Âlem; Yatlar: Sultaniye, İstanbul, Söğütlü, Ertuğrul; Avizolar: Süreyya, Izzeddin, Talia, Ismail, Kllıc Ali, Hayreddin, Gemlik (TNA, ADM, 231-49 (1908).

3 TNA, ADM, 231-49 (1908). 
Şurası'nda görüşüldü ve donanmanın yeniden düzenlenmesi ve personelin modern talim usulleri ile eğitimi için İngiliz Bahriyesi'nden yetkin bir amiralin gönderilmesi uygun bulunarak Londra Sefareti konu hususunda bilgilendirildi. İngiltere, 18 Eylül 1908 'de bu müracaatı olumlu olarak değerlendirildiği bildirildi. Nitekim İngiltere, Osmanlı bahriyesinin kara ordusunda olduğu gibi Alman etkisine girmesini istemiyor ve görevlendirilmesi muhtemel bir Alman bahri misyonunun önüne geçmek istiyordu. Buna paralel olarak 23 Aralık 1908'te İngiliz Bahriyesi'nden seçilen Amiral Douglas Gamble'ın iki yıl süreyle ve bahriyeye dair tüm işler hususunda tam yetkili olarak görevlendirildiği ilan edildi. Ferik rütbesi verilen Gamble başkanlığındaki beş uzmandan oluşan heyet, 2 Şubat 1909'da İstanbul'a geldi ve Osmanlı donanmasındaki hizmetlerine başladı. Gamble ilk olarak donanmada elverişsiz durumdaki gemileri hurdaya çıkararak bahriye idari sisteminde yeniden yapılanmaya yönelik çalışmalar gerçekleştirdi. Eğitim faaliyetlerinde ağırlık vererek Kasımpaşa'daki Gazi Hasan Paşa Kışlası'nda Yeni Er Okulu'nu (Efrad-ı Cedide Mektebi) açtırdı ve ayrıca personel eğitimi için çeşitli alanlarda kurslar düzenlendi. Aktif göreve uygun gemilerden iki filo ve bir filotilla oluşturdu ve Temmuz 1909'da Ege'de seyir tatbikatı yaptırdı. Filo için iki muharebe gemisi, üç kruvazör ve on muhrip inşası yönündeki önerileri, aynı dönemde bahriyenin dretnot cinsi gemiler üzerinde yoğunlaşması nedeniyle hayata geçirilemedi. Başarılı bir hizmet dönemi geçiren Gamble Paşa, bahriye idaresiyle yaşadığı anlaşmazlık ve yaşadığı sağlık problemleri üzerine 26 Ocak 1910'da istifa ederek ülkesine döndü. ${ }^{4}$

Gamble'ın istifasının ardından Bahriye Nezareti 15 Şubat 1910'da Sadaret'e bir yazı göndererek İngiltere'den yeni bir bahriye misyonu getirtilmesi hususunda başvuruda bulundu. $\mathrm{Bu}$ doğrultuda Ingiltere Hariciye Nezareti ile yapılan müzakereleri müteakip 3 Mayıs 1910'da İstanbul'a gönderilen Amiral Hugh Williams, komuta kademesindeki

\footnotetext{
${ }^{4}$ Fahri Çoker, “Osmanlı Bahriyesinde İngiliz Islah Heyetleri (1839-1914)”, Bahriyemizin Yakın Tarihinden Kesitler, Deniz Kuvvetleri Komutanlığı, Ankara, 1994, 166-178, s. 171172; Chris B. Rooney, "The International Significance of British Naval Missions to the Ottoman Empire, 1908-14”, Middle Eastern Studies, 34-1, 1998, 1-29, pp. 1-3; Yaşar Bedirhan, Figen Atabey, “Osmanlı Bahriyesi'nde Yabancı Danışmanlar (1808-1918), Turkish Studies, 8-5, 2013, 127-139, s. 134-135.
} 
dengenin korunması amaciyla mirliva rütbesiyle Osmanlı donanmasındaki görevine başladı. Açılan kurslar yoluyla personelin eğitimine yönelik faaliyetlerde bulunan Williams, Gamble'ın aksine donanmanın yapılandırılması için proje geliştirilen bir teknik müşavir olarak görevini sürdürüyordu. Aynı dönemde Alman yanlısı bürokratların ağırlığının arttığ 1 Osmanlı Hükümeti, yine bir İngiliz bahriye misyonu tarafından 1slah edilmekte olan Yunan donanması ile Ege'de girişilen bahri yarışta üstünlük kazanmak istiyor ve bunun da yüksek tonajlı zırhlı gemiler ve dretnotlar vasıtasıyla gerçekleştirilebileceğine inanıyordu. Williams'ın, kruvazör ve muhrip gibi gemiler ile donanmanın güçlendirilmesinin daha uygun olacağ 1 yönünde fikir belirtmesi ve Temmuz 1910'da İngiltere'nin Swiftsure ve Triumph isimli zırhlı muharebe gemilerini satmayı reddetmesi; Osmanlı İmparatorluğu'nun bu hususta Almanya'ya müracaatıyla sonuçlandı. Aynı yıl Almanya'dan Donanma-yı Osmani Muavenet-i Milliye Cemiyeti tarafından dört muhrip (Muavenet-i Milliye, Yadigâr-ı Millet, Numune-i Hamiyet, Gayret-i Vataniye) satın alındı ve bu gemilerde Alman subayların görevlendirilmesine karar verildi. Ağustos 1910'da ise Brandenburg sınıfı iki Alman zırhlı savaş gemisi satın alınarak Barbaros Hayreddin ve Turgut Reis isimleriyle Osmanlı filosuna dâhil edildi. Ocak 1911'de komuta kademesinde herhangi bir hak ve yetkisinin bulunmadı̆̆ 1 Bahriye Nezareti tarafından açıç̧a ifade edilen Williams, tıpkı Gamble gibi görev süresi dolmadan 3 Şubat 1911'de istifa etti. ${ }^{5}$

Williams'ın istifasını müteakip Osmanlı Hükümeti'nin yeni bir bahriye misyonunun görevlendirilmesine yönelik müracaatı İngiliz Hükümeti tarafından olumlu karşılanarak Amiral Arthur Limpus, Osmanlı donanması bahriye müşavirliği görevine getirildi ve kendisinin seçtiği subaylardan oluşan heyeti ile birlikte Mayıs 1912'de görevine başladı. Çalışmada öncelikle Amiral Limpus'un Osmanlı hizmetine alınma süreci değerlendirilmiş ve kendisinden önce aynı göreve getirilen Douglas Gamble ve Hugh Williams ile yaptığı görüşmeler dikkate alınarak İngiliz görevliler ve Osmanlı Bahriye Nezareti arasında yetki alanı hususunda yaşanan problemler analiz edilmeye çalışılmıştır. İkinci bölümde Limpus'un Osmanlı bahriyesindeki hizmet döneminde hazırladığı raporlar dikkate

${ }^{5}$ Çoker, a.g.e., s. 173-174; Rooney, Ibid., pp. 4-5; Bedirhan, Atabey, a.g.e., s. 135. 
alınarak İmparatorluğun bahriye politikası hususunda arz ettiği görüş ve önerilere yer verilmiş ve Osmanlı bahriyesinde görevli subay ve askerlerin eğitimlerine yönelik faaliyetleri değerlendirilmiştir. Son bölümde ise Amiral Limpus'un gayretleriyle 1914'te yürürlüğe konan Bahriye Nezareti Teşkilat Nizamnamesi incelenerek Osmanlı Bahriye Nezareti'nin yeni teşkilat yapısı ortaya konmuştur.

\section{Amiral Limpus'un Osmanlı Donanması Hizmetine Alınması}

Amiral Williams'ın istifasının ardından Osmanlı Hükümeti'nin İngiltere'den yeni bir 1slah heyetinin gönderilmesine yönelik girişimleri 1912 yılı başlarında gerçekleşmiş ve bu gecikmede 1911'de patlak veren Trablusgarb Savaşı etkili olmuştur. Buna dair ilk teşebbüs, 28 Ocak 1912'de Bahriye Nazırı Hurşid Paşa'nın, acil notuyla Meclis-i Vükela'ya gönderdiği tezkeredir. Burada Williams Paşa'nın kontrat müddetinin 29 Nisan 1912'de sona ereceği ve bahriye dairesinin nizam ve ıslahı ile donanmada görevlendirilecek personelin eğitimi için bir süre daha İngiliz danışma heyetlerine olan ihtiyacın devam ettiği vurgulanıyordu. $\mathrm{Bu}$ nedenle Osmanlı donanması hizmetinde iken önemli yararlılıklar göstererek bahriye ümerasının dostluğunu kazanmış olan Amiral Gamble Paşa'nın tekrar hizmete alınması talep edilmiştir. ${ }^{6}$ Londra Sefiri Tevfik Paşa, 20 Şubat 1912'de ilettiği bilgilendirme notunda Amiral Gamble'ın Eylül 1910'da bir seneliğine İngiliz Bahriyesi Akdeniz İstasyonu Altıncı Kruvazör Filosu kumandanlığına tayin edildiğini ve geri dönüşünü müteakip Osmanlı Hükümeti'nde göreve alınması hususunda kendisine bir mektup gönderildiğini ifade etmiştir. ${ }^{7}$ Gamble'ın görevlendirilmesine dair nihai durum 7 Mart 1912'de Londra Sefiri Tevfik Paşa tarafindan Hariciye Nezareti'ne iletilmiştir. Gamble'ın teklife verdiği cevabı havi mektubun ${ }^{8}$

\footnotetext{
${ }^{6}$ BOA, BEO, 3998-299809-2 (28 Ocak 1912).

${ }^{7}$ BOA, HR.ID, 1829-55-3 (20 Şubat 1912).

8 "Pek müsfikhane yazllmıs olan mektubunuzu aldım. Bu mektubunuzda benim tekrar bahriye müşaviri olarak Osmanl Devleti hizmetine kabulüm hakkında Hükümetin arzusunu beyan buyuruyorsunuz. Bu hususu birkaç sebepten dolayı maalesef kabul edemeyeceğim. Birincisi Istanbul'un havasıyla imtizac edemediğim için bana verilecek vazifeyi şahsi kanaatimce yerine getiremeyeceğim. Bir de şu anki memuriyetim sona erdikten sonra dışarıda geçirdiğim zaman dört seneye varmıs olacaktır ki uzun müddet vatanımda vakit geçirmek istemekteyim. Bundan basska nazar-ı dikkatten uzak tutulmayacak bir manim vardır ki ihtiyarllk vasıl olmus olan validem ile bir müddet beraber bulunmak hissidir. Bir de dişarlda bir memuriyet ettiğim surette Ingiliz Bahriyesinde gelecekte aday olduğum mühim bir mevkii kaybetmis olacağım.
} 
Stratejik İş Birliği ve Askerî Danışmanlık Kapsamında

Osmanlı Donanmasında Amiral Limpus Misyonu (1912-1914)

da iliştirilmiş olduğu yazıda birtakım sebeplerden dolayı Gamble'ın görevi kabul edemediği belirtilerek başka bir amiralin alınması hususunda gerekli teşebbüslerin yapılacağı ve birkaç gün içinde Hariciye Nezareti’ne bilgi verileceği ifade ediliyordu. ${ }^{9}$

Aynı esnada İngiliz Bahriye Nezareti, Gamble'ın yerine Osmanlı Hükümeti'nde görevlendirilmesi için Amiral Arthur Henry Limpus'la görüşmelere başlamıştı. Nitekim 14 Mart 1912'de İstanbul'daki Amiral Williams'ın ekibinde sekreter olarak görev yapan Durman'ın Limpus'a yazdığı mektup, Limpus'un bu teklifi olumlu karşıladığı ve ekibini teşkil etmek için hazırlıklara başladığını gösteriyordu. ${ }^{10} 22$ Mart 1912'de resmî teklif, İngiltere Bahriye Nazırı Winston Churchill tarafından Limpus'a iletildi. Limpus aynı gün yazdığı cevapta Türk Hükümeti'nde bahriye danışmanı olarak görevlendirmekten onur duyacağını belirtiyordu. ${ }^{11}$ İngiliz Bahriyesinin seçimi, Osmanlı Hükümeti'ne 11 Mart 1912'de bildirildi. ${ }^{12}$ Londra Sefiri Tevfik Paşa, Bahriye Nezareti'ni durum hususunda bilgilendirdiği mektubunda İngiliz Hükümeti'nin bu seçiminin reddinin uygun olmayacağını kaydetmiş, ${ }^{13}$ Amiral Limpus'un selefi Gamble Paşa gibi ötekileştirilmemesi, kendisine iyi davranılması ve vazifesini yaparken tam yetki verilmesi hususunda uyarılarda bulunmuş ve Yunanistan Donanması'nı örnek göstererek Yunan filosunun 1slahı ile görevli İngiliz amirale (Amiral Tufnell) tam yetki verildiğine işaret etmiştir. ${ }^{14}$ Aynı yazıya eklenmiş olan Limpus'un özgeçmişi; ${ }^{15}$ Amiralin özellikle Boer Savaşları

Türkiye'ye ve Osmanlılara karşı muhabbetim bakidir. Bundan dolayı affımı istirham ederim. Douglas Gamble" (BOA, HR. ID, 1829-57-2 (tarihsiz, muhtemelen Şubat-Mart 1912; BOA, BEO, 4020-301445, 3-4-5 (11 Mart 1912).

${ }^{9}$ BOA, HR. ID, 1829-57-1 (7 Mart 1912)

${ }^{10}$ Durman'dan Limpus'a, RMG, Caird Archive, LIM -7 (14 Mart 1912).

${ }^{11}$ Churchill 'den Limpus'a, RMG, Caird Archive, LIM-7 (22 Mart 1912); Limpus'tan Churchill'e, RMG, Caird Archive, LIM-7 (22 Mart 1912).

${ }^{12}$ BOA, HR.İD., 1829-58, 2-3 (11 Mart 1912); BOA, HR. ID, 1819-57-7 (28 Mart 1912).

${ }^{13}$ BOA, BEO, 414-301206 (13 Mart 1912).

${ }^{14}$ BOA, HR. ID, 1829-58-1 (13 Mart 1912).

${ }^{15}$ BOA, HR. ID, 1829-58-3 (11 Mart 1912). 7 Haziran 1863'te doğan Limpus, Bahriye Mektebi'ne 5 Temmuz 1876 'da girdi ve 1882 'de Üsteğmen, 1885 'te Yüzbaş1, 1898'de Yarbay, 1900'de Albay ve 23 Ocak 1909'da Tümamiral (Mirliva) rütbelerini ald1. 18841885 tarihlerinde Doğu Sudan'da yer alan Sevakin'deki bahri ve askerî operasyonlarda Albacore gemisinde üsteğmen olarak yer aldı ve Hidivin Bronz Yıldızı adı verilen Misır madalyonu ile ödüllendirildi. 1899-1900 yılları arasında Terrible gemisinin kumandanı 
esnasında gösterdiği üstün başarılarla İngiliz Bahriyesinde itibarlı bir konuma sahip olduğunu gösteriyordu. Osmanlı Hükümeti'nde hizmetine alındığ 1912 yılında 49 yaşında, genç ve bir yıllık amirallik deneyimine sahip bir kumandan olarak, Osmanlı donanmasının reorganizasyonu için gerekli bilgi ve tecrübeyi haiz bir kumandan izlenimi vermekteydi.

Londra Sefareti'nin 13 Mart 1912 tarihli yazısına Bahriye Nezareti tarafindan olumlu cevap verilmiş ve Amiral Limpus'un Osmanlı donanmasında görevlendirilmesine ilişkin mukavelenamenin Bahriye Birinci Dairesi tarafından Türkçe ve Fransızca olarak hazırlanan taslağ Limpus'a sunulmak üzere Londra'ya gönderilmiştir. ${ }^{16}$ Mukavelename taslağ 1,1912 Nisan ayının ilk günlerinde Limpus’a ulaştırılmıştır. Yaptığımız araştırma sonucunda bu metni hem Başbakanlık Osmanlı Arşivi'nde hem de İngiliz Ulusal Denizcilik Müzesi Caird Arşivi'nde muhafaza edilen Limpus'a ait evrakta bulduk. Aynı evrakta Türkçe ve Fransızca hazırlanmış mukavelenamenin İngilizce tercümesi de yer almaktadır. Bunlar birbiriyle karşılaştırılmış ve tamamen aynı olduğu saptanmıştır. 16 maddeden oluşan mukavelenamede dikkat çeken maddeler aşağıda belirtilmiştir: ${ }^{17}$

olarak Güney Afrika'ya gönderildi ve orada görevli deniz tugayına ikinci kumandan olarak atanarak Colenso Savaşı'nda ve Ladysmith'in kurtarılışı için yapılan çatışmalarda üstün hizmetler gösterdi. 1900'de tekrar Terrible'a atanan Limpus, Kuzey Çin'deki operasyonlar boyunca o gemide görevlendirildi ve 1901-1904 yılları arasında Amiral gemisi Gibraltar'ın kumandanı olarak Boer Savaşı'nın son safhasında aktif olarak yer aldı. 1 Temmuz 1905'te Mühimmat Komisyonu'na ve sonrasında Mühimmat Araştırma Meclisi’ne üye olarak atandı ve Albion gemisinin kumandanlı̆̆ görevine getirildiği Ekim 1907'e kadar bu göreve devam etti. 23 Ocak 1909'da Tümamirallik'e terfi etti ve 17 Kasım 1911'e kadar Anavatan filosunda görevlendirildi. Amiralin özgeçmişine, emri altında çalıştı̆̆ kumandanların görüşlerini içeren ifadeler de eklenmiştir. Bunlardan biri Boer Savaşı'nda görevli Albay Scott'a ait olup, Donanma başkumandanına gönderdiği mesajda Limpus'u şu sözlerle anlatmıştır: "Yarbay Limpus, operasyonlar müddetince önemi kanıtlanmıs olan top kundaklarinın yapımında bana oldukça yardımcı oldu. Gerçekte Yarbay Limpus'un sergilediği enerji ve sıkı çalışma olmasaydı Ladysmith için bu silahlar asla zamanında hazir olmayacakti. Durban'in savunmasinda otuz top ve bes yüz askerden sorumluydu ve düşmanın bölgeden çekilmesinde gösterdiği başar ile ne kadar değerli bir subay olduğu kanıtladl. Deniz tugayı ile birlikte düsman takip eden Yarbay, Ladysmith'in güneyindeki tüm operasyonlarda yer aldi. Mevcut durumlar göz önünde bulundurarak şu fikri söylemeye cüret edebilirim ki Yarbay Limpus'un ülkesine olan hizmeti, büyük önem taşımaktadır."

${ }^{16}$ BOA, BEO, 4020-301445-2 (23 Mart 1912); BOA, HR.ID, 1829-59-1 (27 Mart 1912).

17 BOA, HR. ID, 1829-58-7 (Tarihsiz, muhtemelen Nisan 1912); Lowther'dan Limpus'a, RMG, Caird Archive, LIM-7 (4 Nisan 1912). 
Stratejik İş Birliği ve Askerî Danışmanlık Kapsamında

Osmanlı Donanmasinda Amiral Limpus Misyonu (1912-1914)

"Madde 1. Amiral, Osmanl donanmasinin yükselişi için donanmada, merkezde ve mekteplerde gerekli olan bahri ve fenni ilerlemeleri meydana getirmek vazifesiyle mükellef olup donanma kumandan ve fen müşaviridir.

Madde 2. Amiral, çeşitli dallarda uzmanlaşmıs dört subay ve bir sekreterden oluşmak üzere heyetini kendisi tayin edecektir. Bu subaylar, donanmada seyir halinde ve donanmanin gerek ikameti ve gerek tamir dönemi müddetince uzmanlık alanlarna dair kurslarda eğitim verecekleri gibi Bahriye Nezareti'nin emriyle poligon, istasyon ve mensup olduklar daire ve şubelerde görevlerini yerine getireceklerdir.

Madde 3. Amiral ile uzman subaylar Osmanl Devleti hizmetinde bulunduklarn müddetçe Osmanl subayn gibi bahriye nazırnnn emri altında bulunurlar ve rütbelerine mahsus Osmanlı üniforması giyerler.

Madde 15. Osmanl Devleti ile herhangi bir hükümet arasinda savaş vuku bulduğu zaman taraflardan biri arzu ederse kontrat feshedilebilir. Gerek bu suretle mukavelename feshedildiğinde ve gerek Amiral ve heyetinin İniltere Hükümeti tarafindan her ne sebeple olursa olsun Osmanl Hükümeti’ndeki görevlerini terk etmeleri emredildiğinde görevi terk ettikleri müddete kadar maaşlar ödenir.

Madde 16. Amiral ve heyeti Padişah'a ve Osmanl Devletine sadakatle hizmet edeceğini; memleketin kanunlarnna itaat edeceğini; memur bulunduğu vazifeyi başarnl ile yerine getirmek için her türlü çabayn göstereceğini ve Hükümete ait strlar ifşa etmeyeceğini taahhüt ve yemin eder."

Mukavelename henüz taslak halinde olduğu için görev müddetinin başlangıç ve bitiş tarihleri ile maaş miktarları boş bırakılmıştır. Limpus'un kendi evrakında bulduğumuz İngiltere İstanbul Büyükelçisi Gerard Lowther'a ait bir mektup, mukavelename taslağının ilk olarak 2 Nisan 1912'de Lowther tarafından incelendiğini göstermektedir. Lowther olumlu olarak değerlendirdiği mukavelename şartlarında birkaç hususun tadil edilmesinin yerinde olacağına dair Hariciye Nazırı Edward Grey'e görüş bildirmiştir. Bunlardan ilki üçüncü maddede yer alan Fransızca "Ministère" (Vekil) kelimesinin "Ministre" (Nazır) olarak değiştirilmesidir. Lowther, Limpus'un sadece bahriye nazırından emir alacak bir pozisyonda olduğunu belirterek, bu düzeltme yapılmadığı takdirde diğer görevlilerden daha alt bir pozisyonda sayılma riski taşıdığını ifade etmiştir. Lowther ayrıca son maddede yer alan "Amiral, Osmanlı Sultanı ve 
Osmanl Hükümeti'ne sadakat yemini eder" ifadesine de dikkat çekerek İngiliz subaylardan böyle bir şey beklenemeyeceğini ve ifadenin " $A$ miral, Padişah'a ve Osmanl Hükümetine sadakatle hizmet edeceğine, ülkenin anayasasina ve kanunlarina saygı göstereceğine ve kendisine verilecek işleri başarıyla yürütmek için elinden gelen çabayı göstereceğine söz verir." şeklinde değiştirilmesini uygun görmüştür. ${ }^{18}$ Mukavelename, İstanbul'da bulunan Amiral Williams tarafından da incelenmiş ve Williams, birinci maddedeki "Conseiller Technique" (Teknik Danışman) ifadesine dikkat çekerek, bunun bahriye nazırı tarafından bahriye müşaviri unvanından daha alt kademede bir mevki olarak algılandığını, bu iki ifade arasındaki ayırımın kendi hizmet döneminde net bir biçimde ortaya konamadığını ve bu sebeple Limpus'un yetki alanının kısıtlanabileceğini belirtmiştir. ${ }^{19}$ 15 Nisan 1912'de İngiliz Bahriyesi Limpus'u kontratı imzalamaması ve yapılması gereken değişiklikler hakkında Türk Büyükelçiliği ile iletişime geçmemesi hususunda ikaz etmiştir. ${ }^{20}$

\subsection{Amiral Limpus'un Görevlendirme Sürecinde Osmanl} Bahriye Nezareti'nin Tutumu ve Yetki Alanı Problemi

Mukavelename şartları bu şekilde müzakere edilirken Limpus, 3 Nisan 1912'de Türk Büyükelçiliğine başvurarak 30 Nisan'da İstanbul'a varacağını bildirmiş ve hali hazırda orada bulunan sekreter haricindeki İngiliz heyetinin bir müddet daha orada kalmalarını talep etmiştir. ${ }^{21}$ Aynı gün Hariciye Nezareti tarafından Bahriye Nezareti'ne iletilen bu talep, ${ }^{22}$ Bahriye Nazırı Hurşid Paşa tarafından reddedilmiştir. ${ }^{23} 8$ Nisan'da ise

\footnotetext{
${ }^{18}$ Lowther'dan Edward Grey'e, RMG, Caird Archive, LIM-7 (2 Nisan 1912). Lowther, mektubunda ayrıca 3. maddeyle ilgili değişikliğe Hariciye Nazırı Asım Bey'in itiraz ettiğini, kontratın onaylandığını ve düzeltme yapılmasının zor olacağını belirttiğini eklemiştir.

${ }^{19}$ Williams'dan Lowther'a, RMG, Caird Archive, LIM-7 (2 Nisan 1912).

20 Limpus'tan Nicholson'a, RMG, Caird Archive, LIM-7 (15 Nisan 1912); Nicholson'dan Limpus'a, RMG, Caird Archive, LIM-7 (17 Nisan 1912).

${ }^{21}$ BOA, HR. İ, 1829-60-1 (3 Nisan 1912).

${ }^{22}$ BOA, HR. ID, 1829-60-3 (3 Nisan 1912).

${ }^{23}$ BOA, HR. ID, 1829-60-1 (4 Nisan 1912). Hurşid Paşa, Hariciye Nezareti'ne gönderdiği yazıda, Amiral Limpus'un İstanbul'a varışında oradaki Ingiliz heyetiyle karşılaşacağını ve o ana kadar ki durumu tetkik ederek bu hususta bir fikir sahibi olacağını, bunda bir sakınca olmamasına rağmen Bahriye Nezareti'nce Limpus'un heyetini oluşturacak Ingiliz subayların yeni kişiler arasından seçilmesinin fevkalade önemli olduğunu ve bunun Londra Sefiri Tevfik Paşa tarafından münasip bir dille Limpus Paşa'ya izah edilmesi
} 
Stratejik İş Birliği ve Askerî Danışmanlık Kapsamında

Osmanlı Donanmasında Amiral Limpus Misyonu (1912-1914)

Hurşid Paşa, Limpus'un Osmanlı bahriyesindeki görev ve yetkilerinin açılandığı talimatnamenin, Limpus İstanbul'a vardıktan sonra kendisine iletilmesi fikrinden vazgeçildiğini, Hariciye Nezareti'nin Amiral Limpus'a tam yetki verilmesi yönünde yaptığı uyarıların ancak Limpus talimatnameyi İstanbul'a gelmeden inceleyip onaylaması halinde icraya konabileceğini kaydetmiştir. Bahriye Nezareti tarafından hazırlanan talimatname 8 maddeden ibaret olup, ${ }^{24}$ Bahriye Nazırı'nın talebinin aksine Limpus İstanbul'da geldikten sonra 6 Haziran 1912'de kendisine iletilmiştir. ${ }^{25}$ Buna göre Amiral Limpus, Bahriye Nezareti'nin fen müşaviri ve donanma kumandanı olmak üzere iki vazife ile görevlendirilmiştir ve bu unvanlara ait görevler ayrı ayrı açıklanmıştır. ${ }^{26} \mathrm{Bu}$ görevler haricinde Amiral, donanma ve okul gemisinin senelik seyir programını Bahriye Birinci Dairesi ile birlikte düzenleyecek ve görevi esnasında talimatname gereğince icrasını teklif ettiği meseleler hususunda Nazır tarafından verilen emirleri yerine getirmekle mükellef tutulacaktır. Bu esnada Times Gazetesi'nde, İstanbul muhabirinin ilettiği telgraf çerçevesinde yayınlanan bir yazı, bu ihtilafın yabancı basın tarafından da hissedildiğini ortaya koyarken Hariciye Nezareti ile Bahriye Nazırı arasında ufak çapta bir krizin yaşanmasına sebep olmuştur.

gerektiğini bildirmiştir.

${ }^{24}$ BOA, BEO, 4031-302298-3 (8 Nisan 1912).

${ }^{25}$ Bahriye Nazırından Limpus'a, RMG, Caird Archive, LIM-100 (6 Haziran 1912).

${ }^{26}$ Fen müşaviri olarak görevleri: Amiral, Bahriye daireleri, Tersane-i Amire, fabrikalar, havuzlar, Bahriye Mektebi ve bahriye askerlerini teftiş ederek güncel nizamnamelere uygun hale getirilmesi zaruri hususlar ile talim, eğitim ve uygulama gibi konulardaki eksiklikleri Bahriye Nezareti'ne bildirmeksizin derhal düzenleyecek ve süreç hususunda Bahriye Nazırı'nı bilgilendirecektir. Subay ve askerîlerin talim ve eğitimleri için Amiralin maiyetindeki İngiliz subaylar tarafından uzmanlık alanlarına göre kurslar düzenlenecek ve mektepler düzenli olarak teftiş edilecektir. Ayrıca okul gemisi merkezde iken eğitim ve talimleri teftiş edilecek, eksiklikler saptanarak programları değiştirilip düzenlenecektir. Kurslar, mektepler ve okul gemisinde yapilacak imtihanlar esnasında amiral bizzat veya diğer İngiliz subaylarla birlikte hazır bulunarak öğrencilerin liyakatlerini teftiş edip rapor hazırlayacaktır. Donanma kumandanı olarak görevleri: Amiral tarafından kararlaştırılan bahriye manevraları, muavin ve donanma erkân-1 harbiye heyeti ile gemi süvarilerine izah edilecek ve bu manevra ve talimlerin icrası, Amiral tarafindan idare ve kontrol edilecektir. Amiral, bunların neticesi hakkındaki görüş ve önerilerini içeren bir donanma muhtırası hazırlayacak ve bunu bütün gemilere bildirecektir. Donanmayı oluşturan gemiler için gerekli görülen tamirat ve tadilat hususunda gemi süvarileri tarafından verilecek tamirat listelerini kontrol edecek ve onayladıktan sonra Nezarete iletecektir. Donanma merkezde bulunmadığ 1 ve Bahriye Nezareti tarafından başka bir emir verilmediği sürece Amiral, donanmada bulunacaktır (BOA, BEO, 4031-302298-3 (8 Nisan 1912). 
Makale, "Yerel basin son zamanlarda Osmanl bahriyesinin reorganizasyonu ve güçlendirilmesine büyük önem vermiş olsa da, Türk bahriye otoritelerinin mevcut politikalarmın, bu vatansever hedefe katkıda bulunup bulunmayacă̆ şüpheli olabilir." sözleriyle başlamaktadır. Devamında Osmanlı bahriyesi hizmetine yeni atanan Amiral Limpus'un halen İstanbul'da bulunan Williams ve ekibinin tecrübelerinden yararlanmak adına kendi emri altında bir müddet daha İstanbul'da kalmalarına izin verilmesini rica ettiği, bu talebin Bahriye Nezareti tarafından önce kabul edilip sonradan reddedilmesi üzere ekibin Nisan ayı sonunda İngiltere'ye geri döneceği belirtilmiştir. Türk hükümetinin bu tavrının, Amiral Douglas Gamble'ın mücadele etmek zorunda kaldığı engellerin aynısı ile karşılaşacak olan yeni bahriye danışmanının yaşayacağı zorluklara büyük ölçüde katkıda bulunacağından endişe duyulması gerektiği vurgulanmıştır. Limpus'un görev yeri ise; "yerel koşullara ait malumatın mesleki yeterlilik kadar önemli ve entrikantn yoğun olduğu bir yer" olarak tanımlanmıştır. İstanbul muhabiri, Osmanlı Bakanlıklarındaki bu belirgin eğilimin, İngiliz bahriye personelinin verimliliğindeki herhangi bir azalmayla muhtemelen tetikleneceğini ve Osmanlı Bahriyesi tarafından Alman uzmanların takdiminin ciddi bir şekilde ele alındığının da unutulmaması gerektiğini belirmiştir. ${ }^{27}$ Makalenin yayınlanmasının ardından Londra Sefiri Tevfik Paşa Hariciye Nezareti'ne bir yazı göndererek tepkisini dile getirmiştir. ${ }^{28}$

"Ingiltere Bahriyesinin en seçkin amirallerinden biri olan Amiral Limpus'un Osmanl bahriyesindeki görevinde başarll olabilmesi için kendisine tam yetki verilmesi gerektiği, bu hususta Yunanistan donanmasindan ibret alınması ve maalesef Amiral Gamble'a gösterilen muamelenin tekrar sonucu yeni amirali de İstanbul'dan kaçıracak hatalardan çekinilmesinin gerekliliğini daha evvel tarafiniza iletmiştim. Bu babda Times Gazetesi Istanbul muhabiri tarafindan son zamanlarda gönderilmis bir telgrafname bunu manidar bir biçimde izah ediyor. İniliz amiraline birtakım sebepler öne sürerek tam yetki vermekten imtina edilmesi ve bahriye erkânının Amiral maiyetindeki İngiliz subaylarn yetki ve malumatlarna dair elestiride bulunmaları Osmanlı

\footnotetext{
${ }^{27}$ The Times, p. 5, 13 Nisan 1912.

${ }^{28}$ BOA, HR. ID, 1829-58-8 (16 Nisan 1912).
} 
Stratejik İş Birliği ve Askerî Danışmanlık Kapsamında

Osmanlı Donanmasında Amiral Limpus Misyonu (1912-1914)

bahriyesinin ıslah ve yükselişi amacına mani olmaktan basska Ingilizleri de kıracak ve öfkelendirecektir. Bu konunun önemi oranında nazar-ı dikkate alınmasinı rica ederim."

Londra Sefareti, Times'ın 15 Nisan 1912 tarihli sayısında bir düzeltme metni yayınlatarak Amiral Limpus'un talebinin Osmanlı Bahriyesi tarafından dikkate alındı̆̆ını; sözleşmeleri biten ve Osmanlı bahriyesine yaptığı hizmetler, Osmanlı Hükümeti tarafindan büyük takdir kazanan görevlilerin yerine kendi personelini seçmesinin istendiğini ifade etmiştir. ${ }^{29} 22$ Nisan'da Ingiltere Büyükelçisi Lowther, Ingiltere Hariciye Nezareti'ne bir telgraf göndererek Williams ve heyetinin İstanbul'da kalmaması ve Amiral Limpus'un gidiş tarihini erteleyerek Williams ile İstanbul'da karşılaşmamasının uygun olacağını iletmiştir. İngiliz Bahriyesi, bu durumu Limpus'a da bildirmiş ve sebeplerine ilişkin bir açıklama yapılmadığı kaydedilmiştir. ${ }^{30}$ Kontratın imzalanmaması Osmanlı Bahriye Nezareti'ni endişelendirmiş olacak ki Londra Sefaretinden bu hususta bilgi verilmesi istenmiş ve Sefaretten Limpus'a 25 Nisan'da bir mektup gönderilerek imzaların İstanbul'da atılacağ hususunda teyit alınmıştır. 27 Nisan'da Orient Express ile yola çıkacak ve 30 Nisan'da İstanbul'a varacak olan ${ }^{31}$ Amirale refakat etmek üzere Hukuk Müşaviri Reşit Bey'in görevlendirildiği de eklemiştir. ${ }^{32}$

${ }^{29}$ The Times, p. 3, 15 Nisan 1912. Bahriye Nazırı Hurşid Paşa 28 Nisan 1912'de Hariciye Nezareti'ne gönderdiği yazıyla Londra Sefareti'nin tepkisine cevap vermiştir: "Bahriyemiz çeyrek asırdan beri Ingiliz subaylardan bahri ilim ve fenne dair birçok kazanım elde etmiş olup son üç sene zarfinda gerek Amiral Gamble'dan ve gerek Williams Paşa ve maiyetlerindeki subaylardan pek çok istifade edilmistir. Ve özellikle Amiral Gamble'ın, Hükümetin en müşü̈l bir zamanında bahriyemiz için göstermiş olduğu gayret ve fedakârliklar takdire şayan olup bahriyemizde unutulmaz bir hattra bıraktığı aşikâr bulunmuştur. Osmanlı Bahriyesi, Amiral Gamble’ Dersaadet'ten kaçıracak derecede gücendirecek bir harekette katiyen bulunmamıştır. Son dört sene zarfinda geçirdiğimiz ve bahriyemiz için son derece önemli bir devreye ve edinilen tecrübelere göre Amiral Limpus'un bahriyede görevlendirilmesi uygun bulunmuştur. Tam bir emniyet, güven ve başar ile kendisinin bahriyemizi ilerleteceğini ümit etmekteyiz. Times gazetesinin Dersaadet muhabirine atfen yazlmıs olanlar uydurma ve yalan sözlerden ibarettir. Amiral Limpus'a gerekli hürmet ve sayg gösterilecek ve kendisini krracak bir harekette bulunulmayacaktır (BOA, HR. ID, 1829-58-6, (28 Nisan 1912).

${ }^{30}$ Nicholson'dan Limpus'a, RMG, Caird Archive, LIM-7 (22 Nisan 1912).

${ }^{31}$ Limpus'tan Cevat Bey'e, RMG, Caird Archive, LIM-8-1, (9 May1s 1912). Amiral, yola çıkmadan evvel Williams Paşa'dan "ipuçları" başlıklı bir mektup almıştır. 30 Nisan 1912 tarihli bu mektuba göre; İstanbul'da İtalyan Savaşı'nın etkisiyle İtalya'nın müttefiki olan Almanya'nın etkisi büyük düşüş göstermiş ve İngiliz etkisi yükselmişti. Williams bu nedenle Limpus'un görevinin daha net tanımlanacağını ve yaşadığı 
Amiral Limpus, 4 Mayıs 1912'de İstanbul İngiltere Büyükelçisi Lowther'a gönderdiği mektupta kontratın ilk maddesine atıf yaparak görevinin "bahriye danışmanı" olarak değiştirilmesinin uygun olacağını, mümkün olmadığı takdirde "teknik danışman" unvanını almak için de hazır olduğunu belirtmiştir. Maaşların İngiliz sterlini olarak ve kendisi için 3000 ve dört kişiden oluşan ekibinin tümü için 3200 sterlin oranında belirlenmesinin uygun olacağını ve iyi bir diyalog kurduğu Hurşid Paşa'yı da bu hususta bilgilendireceğini iletmiştir. ${ }^{33}$ Büyükelçilik 6 Mayıs'ta Hariciye Nezareti'ne yazdığı yazı ile Amiral Limpus'un heyetini oluşturan

tecrübelerin tekrarlanmayacağını ümit ediyordu. Donanmada iki veya üç ferik rütbeli amiral bulunduğunu ve Limpus'un bu sebeple bunları kendisinin üstü olarak düşünebileceğini belirten Williams, bunun yanlış olacağını zira rütbenin burada bir şey ifade etmediğinin altını çizmişti. Bahriye Müsteşarı Rüstem Bey'in ne kendisi ne de ekibiyle iyi anlaşamadığını ancak İngiltere'nin etkinliğinin artmasına paralel olarak Limpus'a yardımcı olacağını düşündüğünü eklemişti. İşler ümitsiz durumda olduğundan bütçede geçen yıl kesinti yapılmıştı ve 1912 senesi bütçesi neredeyse tüm zamanların en kötü bütçesiydi. Az ya da çok ilerleme kaydedilmiş olan ve devam eden projeler ise İzmit Tersanesi, torpido poligonu, Bahriye Dairesinin reorganizasyonu, bazı deniz askerlerinin hizmet sürelerinin arttırılması, yeni savaş gemileri için mühendislerin eğitimi, çıraklık projesi ve eski gemilerin satımı olarak sıralanıyordu (Williams'tan Limpus'a, RMG, Caird Archive, LIM-7, (30 Nisan 1912).

${ }^{32}$ Cevat Bey'den Limpus'a, RMG, Caird Archive, LIM-7, (25 Nisan 1912). Amiral Limpus'un İstanbul'a varışından hemen önce Londra Sefareti, Hariciye Nezareti'ne de bir yazı göndererek İngiliz Hariciye Nezareti ve Bahriye Dairesi tarafından kontratta değişikliği istenen hususlar hakkında görüş bildirmiştir. Londra Sefiri Tevfik Paşa, Limpus ile bu hususta iletişime geçildiği ve Amiralin İstanbul'a gittiğinde Bahriye Nazırı ile görüştükten sonra imzaların atılacağı hususunda bilgi verdiğini kaydetmiş ve süregelen ikazlarını yenilemiştir: "Cana yakın kişiliğinin yanı sıra, Amiral Limpus Ingiliz donanmasının en seçkin subaylarından biri olup gelecekte İngiltere Bahriye Nazirn ve Anavatan Filosu kumandanı olması muhtemeldir. Ingiltere Hükümeti onun gibi bir danısman seçmekle bize olan dostluğunu kanıtlamışttr. Bu nedenle Sizden ve Bahriye Nazırından bahriyemizin yarar için bize donanmamızın reorganizasyonu için gelmiş olan Amiral Limpus'a en büyük hareket özgürlüğünü vermenizi ve kendisini “Teknik Danısman” veya "Bahriye Danısmanı" unvanı gibi gereksiz tartısmalarla engellememenizi rica ediyorum. Kendisi bana şahsi olarak unvana hiç önem vermediğini ve tüm çabasını ve zekâsını, kendisine düsen görevi yerine getirmeye, yani donanmamızı Osmanl Imparatorluğu gibi büyük bir millete yakışacak üstün bir zemine oturtmaya adayacağını söyledi. Kısacası, Size ve Osmanlı Hükümeti’ne Amiral Limpus görevini icra ederken, miadın doldurmuş bürokrasinin yarattĭ̆ sayısız engel ve zorluklar olmaksızın, istediği tüm imkânlar sağlayarak ve kendisini mümkün olduğunca özgür bırakarak yardımcı olmanız hususunda ısrar ediyorum. Ingiliz danısmanın üstlendiği vazife ile kısa sürede donanmasına bu kadar büyük bir gelisme kaydettiren Yunanistan örneği bize de ilham vermelidir.” (BOA, HR. ID, 1829-64 (25 Nisan 1912).

${ }^{33}$ Limpus'tan Lowther'a, RMG, Caird Archive, LIM-7 (4 Mayıs 1912). 
İngiliz subayların isim listesini takdim etmiştir. Buna göre Limpus başkanlığındaki İngiliz slah heyetini oluşturan subayların isimleri Alan E. Stack (sekreter), Arthur L. Ashby (gemi kumandan1), Frank Elliot (topçu zabiti) ve Guy W. Hallifax (torpido zabiti) olarak sıralanmaktaydi. Limpus ile birlikte İstanbul'a gelen Stack haricindeki subaylar Mayıs ayı içinde İstanbul'a ulaşmış olacaktı. ${ }^{34}$ Böylelikle Amiral Arthur Limpus'un Osmanlı Bahriyesinde görevlendirilmesine dair kontratın imzalanması haricinde tüm işlemler tamamlanmıştır.

Londra Sefareti'nin çabaları 21 Mayıs'ta Bahriye Nezareti'nin değişiklikler hususunda onay vermesiyle sonuçlanmış; ${ }^{35}$ tadil edilip son şekli verilen ve 21 Mayıs'ta bir irade ile akdi onaylanan kontrat, ${ }^{36} 25$ Mayıs 1912 tarihinde Limpus Paşa ve Bahriye Nazırı Hurşid Paşa tarafından imzalanmıştır. ${ }^{37}$ Yapılan değişiklikler genel olarak değerlendirildiğinde İngiliz Bahriyesinin 17 Nisan 1912'de Amiral Limpus'a gönderdiği değişiklik önerileri ile birebir aynı ifadeleri haiz olduğu görülmüştür. ${ }^{38}$ Osmanlı Hükümeti'ni, kontrat taslağında yer alan Londra Sefiri Tevfik Paşa'nın yerine Bahriye Nazırı Hurşid Paşa temsil etmiş ve birinci maddede yer alan "fen müşaviri” ibaresi "umur-1 bahriye müşaviri" olarak değiştirilmiştir. Yedinci maddede yer alan görev müddeti 30 Nisan 1912-30 Nisan 1914 tarihleri olarak belirlenmiş ve dokuzuncu madde yer alan maaşlar hususunda Amirale senelik 3000 İngiliz sterlini ve İngiliz heyetini oluşturan sekreter ve subaylara senelik toplam 3200 İngiliz sterlini ödenmesi kararlaştırılmıştır. Bu meblağın ekip içerisinde tevzii hususu Limpus'un tasarrufuna bırakılmış ve Bahriye Nazırı tarafından onaylanacağı ifade edilmiştir. On beşinci madde değiştirilmemiş, İngiltere Bahriyesinin önerisine paralel olarak yeni bir ekleme yapılmıştır. Buna göre; Osmanlı Devleti ile başka bir devlet arasında savaş vuku bulduğunda Amiral ve diğer İngiliz subaylar donanmada istihdam edilmeyecek; savaş ile ilgili olmayan vazifeler ve eğitimle ilgili hususlarda görevlendirilecektir. Mukavelenamedeki son değişik ise on

\footnotetext{
${ }^{34}$ BOA, HR.İ, 1829-66-2 (6 May1s 1912); BOA, HR.İD, 1829-66- (15 May1s 1912).

${ }^{35}$ BOA, İ.BH, 11-25-2 (21 May1s 1912).

${ }^{36}$ BOA, İ.BH, 11-25-6 (21 May1s 1912).

${ }^{37}$ RMG, Caird Archive, LIM-100 (25 Mayis 1912).

${ }^{38}$ Nicholson'dan Limpus'a, RMG, Caird Archive, LIM-7 (17 Nisan 1912).
} 
altıncı madde yer alan "yemin eder" ibaresinin çıkarılması ve sadece "taahhüt eder" ibaresinin bırakılmasıdır. ${ }^{39}$

5 Haziran 1912'de mukavelename, Meclis-i Mahsus'da müzakere edilerek onaylanmış; ${ }^{40} 6$ Haziran'da ise "Limpus Paşa'nın Suret-i İstihdamına Dair Nizamname-i Hususi" yürürlüğe konmuştur. 13 maddeden oluşan nizamname, 8 Nisan 1912'de Bahriye Nezareti tarafından hazırlanan görev talimatnamesi ile benzer özellikler taşısa da farklı maddeleri de havi olup kontratta vücuda getirilen değişiklikler buraya da yansıtılmıştır. Buna göre; Bahriye Nazırının umur-1 bahriye müşaviri olan Limpus Paşa, donanma kumandanı olmasının yanı sıra bahriye dairesinde görevli efradın bilgi ve becerilerinin arttırılması, savaş gemilerinin etkin kılınması ve bahriye dairesinin her an savaşa hazır bir halde bulundurulmasını sağlamakla mükelleftir. Donanma, tersane ve Bahriye Nezareti'nin etkinliğini arttırmak için gerekli gördügü her tedbiri nazıra rapor edecek; müzakere edildikten sonra rapor, nazır tarafından Bab-1 Ali'ye arz edilecek, onaylanıp hakkında bir irade yayınlanırsa icrası Limpus Paşa'nın nezaretinde gerçekleşecektir. Amiral, Bahriyeye ait tüm birimleri teftiş edecek ve daire başkanları veya gemilerdeki en yetkili subaylara her husus hakkında emir verecektir. Vereceği derslere bahriye ümerasını davet edecek, kara ve deniz kuvvetlerinin etkinliği müşterek hareket etmelerine bağlı olduğundan bu hususu daimî surette subaylara telkin edecektir. ${ }^{41}$

\section{Amiral Limpus'un Osmanlı Donanmasındaki Hizmet Dönemi}

\subsection{Bahriye Politikası ve Eğitim}

1912 yılı Mayıs ayında Osmanlı donanmasında göreve başlayan Amiral Limpus'un 11 Mayıs'ta İngiltere Bahriye Nazırı Winston Churchill'e gönderdiği mektup, Osmanlı bahriyesinin içinde bulunduğu durumu gözler önüne sermektedir: ${ }^{42}$

"Bana zor bir görev verdiniz lakin hiç şüphe yok ki yapilabilecek bir şeyler de mevcut. Bana öyle geliyor ki, ilk adım damısmanlık yapmaya geldiğim kişilerin güvenini kazanmak olmal. Buradaki ortamım tek kelimeyle

\footnotetext{
${ }^{39}$ BOA, İ.BH, 11-25-2 (21 May1s 1912).

${ }^{40}$ BOA, İ.MMS, 152-11-2 (5 Haziran 1912).

${ }^{41}$ BOA, I.MMS, 152-11-4 (6 Haziran 1912); The Levant Herald, s. 1, 12 Haziran 1912.

${ }^{42}$ Limpus'tan Churchill'e, RMG, Caird Archive, LIM-8-1 (11 Mayıs 1912).
} 
Stratejik İş Birliği ve Askerî Danışmanlık Kapsamında

Osmanlı Donanmasında Amiral Limpus Misyonu (1912-1914)

gülünç. Tersaneyi bir görseniz! Bahriye bütçesinin giriş faslını bir okuyabilseniz! Bahriye Binasinın girişini bir görebilseniz! Meşrutiyet'in ilanindan beri biz şimdi sanmm onuncu Bahriye Nazm ile birlikteyiz. Nazır, burada olduğu için memnunum ancak üzülerek söylemeliyim ki savaş bittikten sonra görevine devam etmesi pek mümkün görünmüyor. İzlenimim şu ki burayn idare etmenin yolu tüm yıkıntılar bir araya getirip fark edilmelerini sağlamak olacakttr."

Düşüncelerini Bahriye Nazırı Hurşid Paşa ile de paylaşmak amacıyla 14 Mayıs 1912'de bir rapor sunmuştur. Amirale göre; var olan en büyük sorun karar mekanizmasının başı konumundaki nazırların sık sık değiştirilmesiydi. Yeni atanan görevlilerin, Nezaretin işleyişini kavramakla geçirdikleri dönem büyük zaman kaybına yol açıyordu. Nasıl bir bahri güce sahip olunması gerektiği konusu netliğe kavuşturulmamıştı ve inşası İngiltere'de devam eden savaş gemisinin (Reşadiye) 1913 yılı Ağustos ayında hazır olması bekleniyordu. Bu nedenle bu gemi için acilen tamir ve bakım tesislerinin hazır edilmesi ve geminin mürettebatını oluşturacak subayların ve buhar makinesi için de mühendislerin yetiştirilmesi gerekiyordu. ${ }^{43}$ Limpus Paşa, 19 Mayıs 1912 tarihli ikinci raporunda ise kara ve deniz kuvvetlerinin iş birliğinin önemine dikkat çekmiştir. Bahriye ve ordunun iş birliğinin devamlılığını sağlamak açısından bahriye ümerasından seçilecek subayların Harbiye Mektebi'nin derslerine ve Harbiyeli subayların da Bahriye Mektebi'ndeki belirli derslere alınması faydalı olacaktı. Bu iki harp okulunun birleşik tatbikat yapmaları ve Bahriye Mektebi programına strateji, taktik, uluslararası hukuk, ekonomi ve askerî tarih derslerinin eklenmesi gerekiyordu. ${ }^{44}$

${ }^{43}$ Limpus'tan Hurşid Paşa'ya, RMG, Caird Archive, LIM-8-1 (14 Mayıs 1912).

${ }^{44}$ Limpus'tan Hurşid Paşa'ya, RMG, Caird Archive, LIM-8-1, (19 May1s 1912). Amiral Limpus'un hizmete alınması Türk basını tarafından da ilgiyle takip ediliyordu. 18 Mayıs 1912'de Tanin Gazetesi'nde yayınlanan bir makale, donanmanın güçlendirilmesi amacında Limpus'a olan güvenin yanı sıra Osmanlı vatandaşlarının desteğinin de önemine vurgu yapiyordu: "Ingiliz Amiralinden Osmanl onurunu koruyabilecek bir bahriye projesi istemeliyiz. Bu proje ne kadar büyük olursa olsun, vatanseverliğimiz ve kararlilhğımız da bir o kadar büyük olmalıdır. Kapsamı cesaretimizi kırmamal, aksine bizi heyecanlandırmalddrr. Ancak taahhüt yeterli değildir. Güçlü bir filo, büyük ulusal fedakârllklar, muazzam masraflar gerektirir. Yapabileceğimizi hissediyorsak, geri adım atmayalım. Diyelim ki donanmamız denizlerdeki şerefimizin teminatı olacak. Ancak, bununla başa çıkacak kadar enerjik hissetmiyorsak; düşmanı kapılarımızda görmek, limanlarımızı küstahça bombalamalar ve 
27 Mayıs'ta korvet kumandanı mühendis G. Moore ile iletişime geçen Amiral Limpus, onun da ekibine dâhil olması için İngiliz Bahriyesinden gerekli iznin alındığını kaydetmiş ve başlıca görevinin filodaki subay ve askerlerin eğitimi olduğunu kaydetmiştir. ${ }^{45}$ Böylelikle İngiliz 1slah heyetini oluşturan subayların sayısı 5'e yükselmiştir. Ertesi gün de Londra Sefaretini mukavelenamenin imzalandığ Korvet Kumandanı Hallifax Bey'in 18 Mayıs'ta İstanbul'a vardığını; Frrkateyn Kumandanı Asby Bey'in 3 Haziran'da ve Korvet Kumandanı Elliot Bey'in 1 Haziran'da İstanbul'da olacağını belirtmiştir. ${ }^{46}$ Limpus, Osmanlı Hükümeti üzerinde İngiliz etkisinin artmasını istiyordu. $\mathrm{Bu}$ durum donanmanın reorganizasyonu için geliştireceği projelerin de uygulamasını kolaylaştıracaktı ancak görevinin ilk döneminde bu açıdan en temel zorluğun bütçe sıkıntıları olduğu görülmektedir. Bu durum, 9 Haziran 1912'de Bahriye Nazırı Churchill'e gönderdiği mektuba da yansımıştır: ${ }^{47}$

“Buraya geldiğim günden beri güvenlerini kazanmaya başladiğım hissediyorum. Bana yavaş yavaş da olsa daha fazla icra yetkisi veriliyor. Önümüzdeki üç veya dört sene zarfinda yardıma olan ihtiyaçlarn devam edecek ve sahip olunan bütçe kayda değer bir zorluk. Bu sorunla yakın zamanda yüzleşecekler ve kanımca kendileri için para toplayacaklar. Muhakkak ki biri onlara finansal açıdan yardım edecek, mühim olan ise bunu kimin yapacağı ve açık ki bu yardım bir şey beklenerek yapılacak. Buradaki ortam hala gülünç lakin insanlar bu zengin ama gelişmemiş ülkenin kalkınması ve mevcut bozulmaların düzeltilmesi adına bir amaç ve kararlllı̆̆a sahip görünüyorlar. Onlara kim yardım edecek?”

Limpus Paşa, bu yardımın İngiltere tarafından yapılmasının İngiltere açısından faydalı olacağını düşünüyordu. 1 Haziran'da İstanbul'a varan ve gelmeden evvel Asby Bey ile birlikte inşa halindeki Reşadiye gemisini ziyaret eden Elliot Bey'in verdiği rapor, inşaatın yolunda gittiğini

gemilerinin koruması altında topraklarımıza çıkmaları bizi hiç aşağılamıyorsa, hiçbir şey yapmayalım. Güçlü bir donanmaya sahip olmak için özel bir vergiye ihtiyactmız var. Yillık iki milyon sterlin tutarnda özel ve ek bir fasll ile Bahriye Nezareti, Izmit'te büyük bir tersane kurarak dretnot siparişi verebilecek." (RMG, Caird Archive, LIM-8-2 (18 Mayıs 1912).

${ }^{45}$ Limpus'tan Moore'a, RMG, Caird Archive, LIM-8-1, (27 May1s 1912).

${ }^{46}$ Limpus'tan Cevat Bey'e, RMG, Caird Archive, LIM-8-1, (28 May1s 1912).

${ }^{47}$ Limpus'tan Churhill'e, RMG, Caird Archive, LIM-8-1, (9 Haziran 1912). 
gösterirken herhangi bir gecikmenin önlenebilmesi adına Bahriye Nezareti'nden bir talimat gönderilmesi gerektiğine işaret etmiştir. ${ }^{48}$ 3 Haziran'da Asby Bey İstanbul'a varmış ve Limpus Paşa tarafından kendisine bir talimatname verilmiştir. Buna göre; Asby, beş kişiden oluşan İngiliz misyonunun karada ve denizdeki amiri olarak Limpus Paşa'nın yokluğunda kendisinin yerine geçerek Sekreter Stack Bey ile iş birliği içerisinde mevcut işlerin yürütülmesini sağlayacaktır. Donanma programı paralelinde Lloyds Sinyal İstasyonu'nun tesisi ve personelin eğitimi ile ilgili düzenlemelerin idaresinden sorumlu olacak ve bir Navigasyon Mektebi'nin kurulmasına yönelik çalışmalar gerçekleştirecektir. Limpus, Asby Bey nezdinde tüm İngiliz heyetine hitaben kaleme aldığ talimatnamede dilin Türk ve İngiliz görevliler arasındaki en büyük bariyer olduğunu ancak sabır ve dikkat ile bu sorunun aşılabileceğini belirtmiş ve Türklere bir şeyler öğretmeye gelen İngilizlerin, onlardan da öğrenecek çok şey olduğunu unutmamaları gerektiğini vurgulamıştır. ${ }^{49}$

Amiral Limpus, Moore Bey haricinde ekibini oluşturan üyelerin hepsi görevine başladıktan sonra donanma programının boyutu hususunda bir rapor hazırlayarak Hurşid Paşa'ya sunmuştur. Bir önceki raporunda nasıl bir deniz gücüne sahip olunması gerektiği sorusunun ülkenin diş politikasına bağlı olduğunu hatırlatan Limpus, Türkiye'nin sahip olması gereken bahri dış politikayı şu maddelerle açıklamıştır: ${ }^{50}$

- Türkiye agresif bir tutum izlemek ya da yeni bir toprak elde etmek niyetinde değildir. Ancak şu an sahip olduğu toprakları, hukuki haklarını ve çıkarlarını dışarından gelecek bir tecavüze karşı korumak zorundadır.

- Türk donanması kesinlikle Yunan Donanmasından daha güçlü olmalidir.

- Türk donanması, uzun müddet boyunca İtalya ve Avusturya donanmaları üzerinde üstünlük kurmayı ümit edemez. Ancak donanma o kadar güçlü olmalıdır ki İtalya ve Avusturya, Akdeniz veya Kızıldeniz kıyılarına askerî birlik göndermenin tehlikesinin

\footnotetext{
${ }^{48}$ Limpus'tan Hurşid Paşa'ya, RMG, Caird Archive, LIM-8-1, (2 Haziran 1912).

${ }^{49}$ Limpus'tan Asby'e, RMG, Caird Archive, LIM-8-1, (4 Haziran 1912).

${ }^{50}$ Limpus'tan Hurşid Paşa'ya, RMG, Caird Archive, LIM-8-1, (5 Haziran 1912).
} 
farkına varmalı ve Türk donanması ile karşılaşıp yenene kadar bunun imkânsız olacağını düşünmelidir.

- Aynı şekilde, donanmamızın gücü, Rusya'nın Karadeniz üzerinden asker göndermesini tehlikeli hale getirecek kadar etkili olmalıdır.

Osmanlı İmparatorluğu'nun bu gereksinimler karşısında bahri politikasının tekrar ele alınması gerektiğini savunmuş ve 1 Nisan 1912'de arz edilen donanma programının ihtiyaç duyulandan daha geniş kapsamlı olduğunu vurgulayarak birtakım değişiklikler önermiştir. Buna göre; programda teklif edilenin aksine donanmanın altı değil dört adet zırhlı savaş gemisi ile takviye edilmesi yeterlidir. İzmit'te inşa edilecek yeni deniz üssü için havuz ve tersane inşası zaruridir ve acilen özel bir okul gemisi inşa edilmelidir. Program küçültülse bile bütçesi hala büyük boyutta olacağ 1 için bahriye bütçesine ek bir madde halinde ilave edilmeli ve donanmanın sürekli artan ihtiyaçları göz önünde tutularak yeterli oranda belirlenmelidir. Programın öncelikli hedefi İngiltere'de inşa edilen gemi ve yeni deniz üssünün tesisi olarak belirlense de Limpus'a göre personelin talim ve eğitimi ile filoda var olan gemilerin tamir ve bakımlarının mümkün olan en iyi şekilde tatbiki hayati önem arz ediyordu. Bu sebeple bütçeden bu konular için de yeterli oranda pay ayrılması gerekiyordu. ${ }^{51}$

Bu amaç doğrultusunda 3 Haziran 1912'de heyetiyle birlikte Bahriye Mektebi'ni ziyaret ederek Bahriye Nazırı Hurşid Paşa'ya bu hususta bir rapor sunan Limpus Paşa, mektepteki günlük yaşamı tam anlamıyla gözlemleyebilmek ve bir hazırlık yapılmasına mani olmak amacıyla haber vermeden gittiğinin altını çizmiştir. Mektep hakkındaki bilgisinin 1909'da Gamble Paşa'nın verdiği rapora dayandığını belirten Amiral, mektebin şu anki vaziyetiyle 1909 'daki durumuna nazaran ilerleme kaydettiğini ve Sermed Bey ile Holland Bey'in oldukça uyumlu çalıştı̆̆ını sözlerine eklemiştir. Limpus'a göre Bahriye Mektebi'nin başarısı büyük ölçüde öğrencilere aşılanan ruha ve eğitime bağlıydı ve orada yapılacak reformlar, bahriye hizmetinin karakterini ve verimliliğini hayati bir şekilde etkileyecekti. Öğrenciler mektebe 13 yaş civarında alınmaktaydı ve orada dört seneden fazla kalmamaları, 17 yaşına geldiklerinde filodaki görevler hususunda sorumluluk

\footnotetext{
${ }^{51}$ Limpus'tan Hurşid Paşa'ya, RMG, Caird Archive, LIM-8-1, (5 Haziran 1912).
} 
Stratejik İş Birliği ve Askerî Danışmanlık Kapsamında

Osmanlı Donanmasında Amiral Limpus Misyonu (1912-1914)

almaya başlamaları gerekiyordu. Öğrenci bu kadar uzun süre mektepte tutulurlarsa bir subayın sahip olması gereken liderlik özellikleri, askerler üzerindeki komuta gücü ve sorumluluk gibi nitelikleri elde etmeleri çok güç olacaktı. Bu nedenle mektepte kaldıkları süre boyunca aşağıda sıralanan nitelikleri kazanmaları için büyük gayret gösterilmesi gerekiyordu:

- Allah'a, Sultan'a ve Osmanlı İmparatorluğu'na karşı güçlü bir görev duygusu.

- Her biri muharebe hizmeti için görevlendirilecek subaylar olarak yetiştiği için içselleştirmeleri zaruri olan güçlü bir minnet duygusu.

- Görevi her zaman kişisel çıkarlardan önce gözetme alışkanlığından kaynaklanan bir rekabet ve onur duygusu.

Limpus, özelikle son maddenin iyi bir subayda olması gereken en önemli nitelik olduğunu vurgulayarak bunun Bahriye Mektebi'nde de yerleştirilmesi için uygun bir ödül ve ceza sisteminin işe yarayacağ kanısındaydı. Bu sebeple belirgin yeteneğe sahip ve başarılı olan öğrencilere küçük ödüller, bazı ekstra görevler ve ayrıcalıklar verilmesi uygun olacakt1. ${ }^{52}$ Limpus Paşa'nın ziyaretini müteakip 13 Haziran 1912'de yayınlanan Bahriye Zabitanın Terfi-i Rütbe Nizamnamesi'ne göre o dönemde Bahriye Mektebi'nde mevcut bölümler Güverte, Çarhçılık ve İnşaiye olarak sıralanmaktaydı (Madde 3). Eğitim süresi dört sene olarak belirlenmişti ve bu süre sonunda yapılacak genel sinavlarda başarı gösterenler okul gemisine gönderilerek iki sene daha eğitimlerine devam ediyorlardı. İki sene sonunda tekrar sınav yapılıyor, güverte sınıfında başarılı olan subaylar mülazım-1 sani unvanıla bir savaş gemisinde iki sene müddetle görevlendiriyordu (Madde 34). Bu süre zarfında bölük idaresi, vardiyaların düzenlenmesi,

52 Limpus'tan Hurşid Paşa'ya, RMG, Caird Archive, LIM-8-1, (10 Haziran 1912). Limpus Paşa aynı raporda mektebe uygun olmayan öğrencilere uyarıyı takiben üç ay süre verilmesi ve bir değişiklik görülmezse ilişiklerinin kesilmesi gerektiğini belirtmişti. Öğrenci alımlarında kontenjan 20 kişi olarak belirlenmeli ve sayıları çok fazla olan ögretmenlerden bir kısmı gönderilmeliydi. 2'si İngilizce ve 2'si bilim branşlarında olmak üzere dört İngiliz öğretmenin işe alımı gerçekleştirilecekti. Öğretmenlerin tümü Heybeliada'da ikamet edecek ve değişim yapılacaksa dönem sonu beklenecekti. Tüm öğrenciler yılda iki kez göz muayenesinden geçirilecek, kahvaltılarına her gün için süt ve haftada üç kez bal ve reçel eklenecekti. Okul üniformaları yedeklenecek ve talimler için ayrı birer kıyafet temin edilecekti. Spor sahası yeterince büyük olmadığından genişletilecek ve bazı jimnastik aparatları eklenecek, ayrıca öğrenciler kürek, yelken ve yüzme gibi sporlara teşvik edilecekti. 
filo manevraları esnasında vardiya zabitliği, genel talimlerde bölük kumandanlığı gibi görevleri icra etmeleri ve yeterliliklerini gösteren ve mensup oldukları geminin süvarisi tarafindan verilecek olan bir tasdikname almaları gerekiyordu. Bu belgeyi alanlar yüzbaşllı̆a terfi ediliyordu. Çarhcı ve İnşaiye mülazımları ise Bahriye Mektebi'nde bir sene daha eğitim görüyor, sene sonunda yapılan genel imtihanda başarılı olduktan sonra diploma alarak bir sene müddetle kendi dallarına göre belirlenecek fabrikalarda görevlendiriliyordu. Süre sonunda tasdikname almaya hak kazananlar yüzbaşı unvanıyla donanmada görevlendiriliyordu (Madde 43). ${ }^{53}$

3 Ekim 1912'de Limpus'un donanmanın 1slahı hususunda Bahriye Nazırı'na sunduğu kapsamlı rapor, 2 Kasım 1912'de Harbiye Nezareti'ne takdim edilmiştir. Beş aylık hizmet dönemi boyunca filoyu henüz göremese $\mathrm{de}^{54}$ Osmanlı bahriyesini oluşturan diğer birimlerde incelemelerde bulunmuş ve mevcut bütçeye göre alınması gereken tedbirleri birer birer izah etmiştir. Osmanlı İmparatorluğu'nun sahip olduğu toprakların genişliği ve uzun sahil şeridi itibarıyla güçlü bir donanmaya sahip olmaksızın çıkarlarını koruyamayacağının altını çizen Limpus, barış zamanı gerek liman ve sahillerin gerekse deniz ticaretinin güvenliğinin ancak güçlü bir donanma ile sağlanabileceğini belirtmiştir. Savaş zamanında ise kara kuvvetlerinin güvenli bir biçimde sevkiyatı, düşman donanmalarının asker sevkiyatının önlenmesi ve düşman donanması ile girişilecek deniz muharebeleri için güçlü bir filoya ihtiyaç vardır. Raporunun devamında Limpus, donanmanın boyutuna ilişkin düşüncelerini de açıklamıştır. Ona göre Osmanlı İmparatorluğu'nun ihtilafa düşme olasılığının en yüksek olduğu devletler Yunanistan, Bulgaristan, Avusturya, İtalya ve Rusya'dır. Osmanlı donanması, Yunan donanmasından daha üstün bir seviyede tutulmalı ve Avusturya donanması ile tek başına mücadele etmeye hazır bir hale getirilmelidir. Bu durumun Bulgaristan, İtalya ve Rusya'nın Osmanlı Hükümeti’ne karşı agresif bir bahri politika izlemeleri hususunda da caydırıcı bir etkisi olacaktır. Limpus Paşa, Osmanlı donanmasının

\footnotetext{
${ }^{53}$ BOA, A.DVN.MKL, 53-17, 13 Haziran 1912.

${ }^{54}$ Limpus, Trablusgarp Savaşı devam ettiği için mukavelenamesinin 15. maddesi gereği, Mayıs 1912'den bu raporun verildiği Ekim 1912'ye kadar ki dönemde filoda aktif olarak yer alamamıştır.
} 
Avusturya donanmasına denk bir güçte olması gerektiğini savunmuştur ve O'na göre, sadece filoya değil aynı zamanda tersane ve eğitime de yeterli bir bütçe ayrılması gerekmektedir. Donanmayı, Avusturya donanmasının seviyesine ulaştırmak için yapılacak masraflar göz önüne alındı̆̆ında toplam 18 milyon İngiliz sterlini tutarında bir bütçe tayin edilerek bunun gelecek 5-6 seneye eşit bir biçimde dağıtılması, başka bir deyişle modernizasyon için ayrılan bütçenin senelik 3-3,5 milyon İngiliz sterlinine yükseltilmesi gerekmektedir. Bu mümkün olmadığı takdirde bahri politika Yunan donanmasından daha üstün bir donanmaya sahip olmaya odaklandırılarak, yeni savaş gemileri, tersane ve havuz projeleri için toplam 6 milyon sterlin tutarında bütçe tayin edilmeli ve bundan senelik 1.750.000 İngiliz sterlini fevkalade bütçe ayırılıp, sadece bu projeler için kullanılmalıdır. ${ }^{55}$

Raporunun ikinci kısmını deniz askerlerinin alımı ve talimleri hususunda yapılacak düzenlemelere ayıran Limpus Paşa, bahriyeye alınacak efradın askerlik hizmetlerini bahriyede icra etmek isteyenler arasından seçilmesini ve bunların talimleri için hususi bir mektebin tesis edilmesi gerektiğini ifade etmiştir. Ayrıca fevkalade alımların gerektiği olduğu dönemlerde, mecburi hizmet döneminden daha uzun süre hizmette tutulmaları için bir yöntem geliştirilmesini ve makine sanayi küçük zabiti unvanıyla bir sınıf teşkil edilmesini tavsiye etmiştir. Amiral ayrıca kömür, yağ, elbise ve erzak depoları da dâhil olmak üzere donanma için gerekli olan her türlü levazımın satın alınması, muhafazası ve dağıtımdan sorumlu olan birimin yeniden ve tamamiyla revize edilmesi ve buna nezaret etmek üzere bir muavinin görevlendirilmesi gerektiğini belirtmiştir. Büyük savaş gemilerinin tamir ve bakımı için bir havuz inşasının aciliyetine dikkat çekmiş ve bunun kuru ya da yüzer havuz mu olacağının süratle karara bağlanması gerektiğinin altını çizmiştir. Bu tedbirler haricinde ikinci derecede önemi haiz meseleleri de torpido istasyonu tesisi, Haliç Tersanesi'nde kalabalık teşkil eden eski gemi ve köhne levazımın satışı, Trablusgarp Savaşı'ndan sonra İngiltere'ye gönderilecek otuz adet subaya

${ }^{55}$ BOA, A.MKT.MHM, 742-15 (2 Kasım 1912). 
verilecek eğitim, Reşadiye gemisinin mühimmatı ve donanma, havuzlar ve tersanenin tamir masrafları için talep edilen ek bütçe olarak sıralamıştır. ${ }^{56}$

26 Ocak 1913 tarihinde Bahriye Nazırı Mahmud Paşa'ya arz ettiği rapor ise devam eden savaş hususunda Nezaretin Amiral Limpus'tan danışmanlık talep ettiğini göstermektedir. Raporunun ilk bölümünde mukavelenamesinde de açık bir biçimde belirtildiği üzere bu hususta görüş bildirmesinin mümkün olmadığını izah etmiş, bu durum sebebiyle filoda aktif görev alamadığını ancak ekibiyle birlikte bahriye dairesine ait diğer meseleler için (bahriye askerlik hizmetine dair nizamnamelerin revize edilmesi ve subay ve askerler için kursların açılması) gayretle çalıştıklarını ifade etmiştir. Amirale göre bütçe, hala ilerlemenin önündeki en büyük engel konumundadır ve savaş bittikten sonra filonun Haliç'e çekilerek tamire alınması gerekmektedir. Bu sürece bizzat kendisinin ve ekibinin nezaret edeceğini belirten Limpus Paşa, sekiz buçuk aylık hizmet dönemi boyunca sadrazam ve bahriye nazırlarının sıklıkla değiştirildiğini, bunun da filonun komutasının defalarca el değiştirdiği anlamına geldiğini vurgulamış; filonun ilerlemesi ve etkinliğinin arttırılması amacıyla takip edilen bahriye politikası için komuta kademesindeki sık değişiklilerin yıkıcı bir etkisi olacağının altını çizmiştir. ${ }^{57}$

Subayların eğitimi için çeşitli dallarda kurslar tertip edilmesi amacıyla Limpus Paşa tarafından hazırlanan Zabitan-ı Bahriyenin Umumi Kurslarına Mahsus Nizamname 25 Eylül 1913'te Sadaret'e takdim edilmiş ve 1 Ekim 1913 'te onaylanmıştır. Modern savaş gemilerinin makine ve mühimmat bakımından eski gemilere nazaran son derece ileri düzeyde olması nedeniyle bunlardan gereği gibi istifade edilebilmesi için bahriyeye mensup olan subayların kendi alanlarında bilgi ve becerilerinin geliştirilmesi ve tecrübe kazandırılmasının önemine dikkat çekilmiştir. Diğer devletlerin donanmalarında da olduğu gibi her bir bahriye subayının seyr-i sefain, topçuluk, çarhcılık ve torpidoculuk (elektrik ve telsiz telgraf dâhil olmak üzere) alanlarında savaş gemilerinde kullanacağı araçlara dair bilgi sahibi olmasının amaçlandığı kaydedilmiş ve bu alanlarda açılacak her bir kurs için birer mektep tesis edildiği belirtilmiştir. Buna göre her birinin

\footnotetext{
${ }^{56}$ BOA, A.MKT.MHM, 742-15 (2 Kasim 1912).

${ }^{57}$ Limpus'tan Mahmud Paşa'ya, RMG, Caird Archive, LIM-100, (26 Ocak 1913).
} 
Stratejik İş Birliği ve Askerî Danışmanlık Kapsamında

Osmanlı Donanmasında Amiral Limpus Misyonu (1912-1914)

müddeti sekiz hafta olarak belirlenen kurslara 1912'den önce bahriyeye giren veya Bahriye Mektebi'nden mezun olan tüm subayların katılmaları ve imtihanları başarıyla geçmeleri mecbur tutulmuştur. Üç sene veya daha uzun süre bahriyede bulunup, Osmanlı donanmasında veya yabancı bir devletin donanmasında bir sene hizmet vermiş güverte ve makine yüzbaşılarıyla mülazım olanların, daha önce aldıkları kurslara devam etme zorunlulukları olmamasına karşın imtihanların birine veya hepsine katılmalarının talep edilebileceği belirtilmiştir. Kurslara yazılan subayların tayini kıdem sırasına göre yapılacak, her kursun sonunda o kursun alanına mahsus imtihan uygulanacaktır. İmtihan sonunda toplam puanının \%50'sinden daha az puan alan subaylar, imtihanda başarısız sayılacak, tekrar imtihana giremeyecek ve aynı kursu tekrar alamayacaktır. Bu durum, subayların terfi ve istihdam durumunu sınavları kazananlara göre olumsuz etkileyecektir. Seyr-i sefain ve topçuluk kurslarının her ikisinden veya dört tane olan çarhçılık kursunun ikisinden geçemeyen subaylar, artık denizde istihdam edilmeyecek ve muvazzaf bulundukları rütbede terfi edemeyeceklerdir. Bu durumdaki subaylar deniz hizmetinde bulunmaz ya da deniz hizmetine alınıp hizmetleri esnasında haklarında olumsuz rapor verilirse derhal emekli edileceklerdir. Imtihanlarda toplam puanın \%50'sini kazanan subaylara üçüncü, \%75'ini kazanan subaylara ikinci ve \%90'ını kazanan subaylara birinci dereceden birer diploma verilecektir. Ayrıca kurslar için tesis edilen mekteplerdeki eğitmenlerin Limpus Paşa tarafından seçileceği ve sayılarının Seyr- Sefain Mektebi için 3, Topçuluk Mektebi için 3, Torpido Mektebi için 4 ve Çarhcıllk Mektebi için 10 olarak belirlendiği ifade edilmiştir. ${ }^{58}$

\subsection{Bahriye Nezareti Teşkilat Yapısının Reorganizasyonu}

Bahriye Nezareti'ni oluşturan daire ve şubelerin yeniden tanzimi, Limpus Paşa'nın hizmet döneminin ilk günlerinden itibaren dikkat çektiği en mühim meselelerden biri olmuş ancak Cemal Paşa'nın Bahriye Nazırı olarak görevlendirildiği Şubat 1914'e kadar bu hususta kayda değer bir gelişme vücuda getirilememişti. ${ }^{59}$ Limpus Paşa, Osmanlı Bahriye

\footnotetext{
${ }^{58}$ BOA, İ.MMS, 170-25 (1 Ekim 1913).

${ }^{59} \mathrm{Bu}$ durumun oluşmasında Amiral Williams'ın bahriye müşavirliği döneminde Bahriye Müsteşarlı̆̆g'na getirilen Rüstem Paşa'nın ve Harbiye kökenli Bahriye Nazırları Salih Paşa ve Mahmud Muhtar Paşa'nın Alman yanlısı politikalarının etkisi
} 
Nezareti'nin yeniden yapılandırılma sürecinde İngiliz Bahriyesi organizasyon yapısının model alınmasını istiyordu. Nitekim Temmuz 1912'de Bahriye Nazırı olarak tayin edilen Mahmud Muhtar Paşa'nın talebi üzerine 14 Eylül 1912'de İngiliz Bahriyesinin o dönemde geçerli olan teşkilat yapısına dair bir rapor hazırlamıştı. Buna göre; Birinci Lord olarak isimlendirilen Bahriye Nazırı'nın idari mekanizmanın en üstünde yer aldığı İngiliz Bahriye teşkilat yapısı, aynı dönemde dört daire ve sivil görevliler tarafından idare edilen şube ve müsteşarlıkların dâhil olduğu bir idari yapıyı haizdi. Bahriye Nazırı filoya ve personele dair tüm işlerin en üst karar mercii ve genel idarecisi olarak görevlendirilirken Bahriye Birinci Lordu savaş organizasyonu ve filonun dağılımı; Bahriye İkinci Lordu askerî personel; Bahriye Üçüncü Lordu savaş gemileri, mühimmat ve tersaneler ve Bahriye Dördüncü Lordu levazım ve nakliye alanlarının idaresinden sorumlu tutulmuştu. Bahriye Sivil Lordu bahriye binaları ve bunlara dair ödeneklerin idaresiyle görevlendirilmiş; Bahriye İkinci Sivil Lordu ise mukavelenameler ve tersanelerin malzemeye dair idaresi görevlerini üstlenmişti. Bahriye bütçesinin idaresi Parlamento Müsteşarının uhdesine verilirken Daimi Müsteşar ise Nezaretin işleyişi ve yazışmalar hususunda yetkili kılınmışt1. ${ }^{60}$

Cemal Paşa, Hattralar isimli eserinde 1914 yılı başında Bahriye Nazırı olarak görevlendirildiğinde Limpus Paşa ile bir görüşme yaptığını ve bu görüşmede Limpus Paşa'nın ilk olarak bahriye dairelerinin düzenlenmesi yönünde görüş bildirdiğini kaydetmiştir. Amiral Gamble ve Limpus Paşa'nın daha önce Bahriye Nezareti'ne arz ettikleri raporları tetkik eden Cemal Paşa, iki müşavirin de Şura-yı Bahriye'den şikâyetçi oldukları sonucuna varmıştır. Buna göre sorumluluk almaktan kaçma eğiliminde olan daire reisleri, kendi yetki alanlarına ilişkin hiçbir karar almayarak meseleleri; bahriyeye ilişkin her türlü kararın müzakere edildiği Şura-yı Bahriye'ye havale ediyordu. Bu durum meclisin iş yükünü arttırıyor ve herhangi bir teklif ya da karar sonuca bağlamadan uzun müddet dosyalarda bekletiliyordu. Limpus Paşa, ayrıca Dördüncü Daire ile Muhasebe

olduğu belirtilmiştir (Rooney, The International Significance of British Naval Missions...”, p. 4).

${ }^{60}$ Limpus'tan Mahmud Muhtar Paşa'ya, RMG, Caird Archive, LIM 61-1, (14 Eylül 1912). 
ve Yoklama Müdüriyeti’ndeki işleyişin acilen yeniden düzenlenmesine dikkat çekerek yapılması gereken reformların önündeki en büyük engel olarak Bahriye Müsteşarı Mirliva Rüstem Paşa'yı göstermişti. Sunduğu bazı önerilerin daire reisleri tarafından onaylandığını, ancak bu hususları Rüstem Paşa ile müzakere ettikten sonra kendi fikirlerinin tam tersi bir tutum sergilediklerini belirtiyordu. Limpus Paşa'dan aldığ geri bildirim Cemal Paşa'nın önce Şura-yı Bahriye'yi kaldırması ve sonra Müsteşar Rüstem Paşa ve aynı tutumda olan iki liva amiral, Sıhhiye Müfettişi Faik Paşa, birkaç miralay, kaymakam ve binbaşıyı emekliye sevk etmesiyle sonuçland. Böylelikle Nezaret, yapılacak islahatlara muhalefet gösteren grubun engellemelerinden kurtarılmış oldu ${ }^{61}$ Limpus Paşa'nın önerileriyle Bahriye Müsteşarlığı ve Şura-yı Bahriye'nin kaldırılmasının ardından yeni teşkilat nizamnamesi hazırlanarak 1 Nisan 1914'te Bahriye Nazırı Cemal Paşa tarafından Sadaret'e arz edildi ve aynı gün Meclis-i Mahsus'ta müzakere edilerek uygun bulunmasını müteakip 2 Nisan 1914'te yayınlanan irade ile yürürlüğe kondu. ${ }^{62} 83$ maddeden oluşan Bahriye Nezareti Teşkilat Nizamnamesi'ne göre oluşturulan yeni idari sistem aşağıda yer alan birimlerden oluşmaktaydı:

${ }^{61}$ Cemal Paşa, Hattralar, (Yay. Haz. Alpay Kabacalı), Türkiye İş Bankası Kültür Yayınları, İstanbul, 2006, s. 108-110.

${ }^{62}$ BOA, İ.MMS, 183-5 (1 Nisan 1914); BOA, İ.MMS, 183-5 (2 Nisan 1914); RMG, Caird Archive, LIM-162 (2 Nisan 1914). 


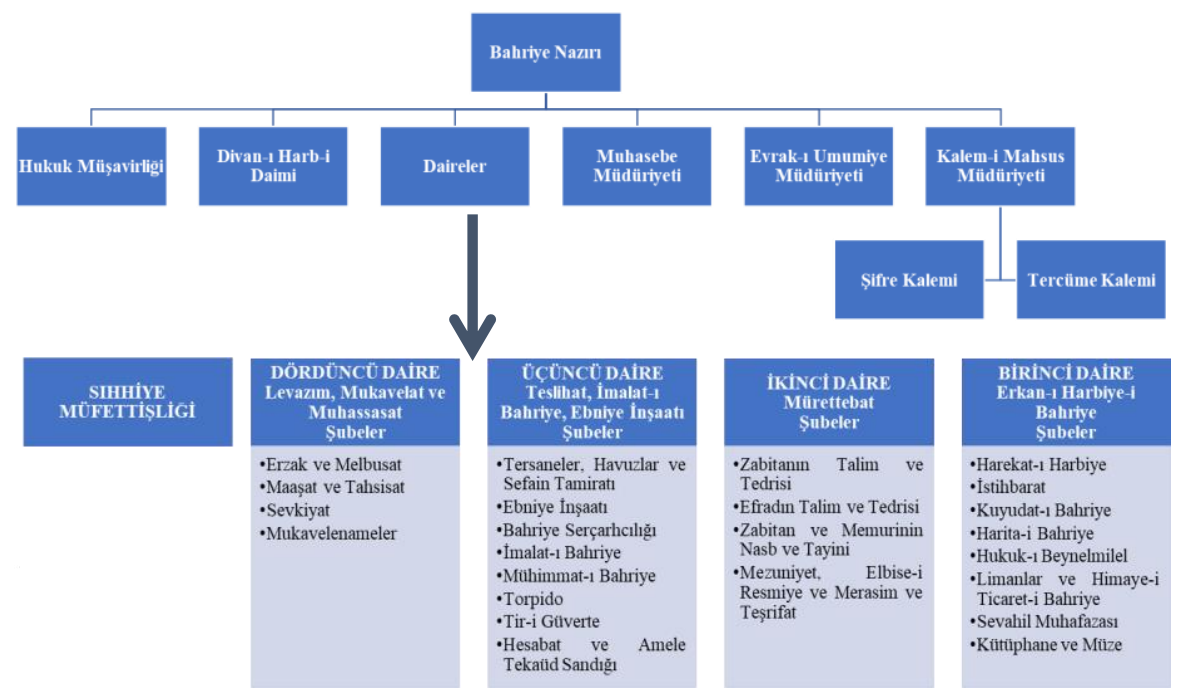

Şekil 1. 2 Nisan 1914'te yürürlüğe konan Bahriye Nezareti Teşkilat Nizamnamesi'ne göre Osmanlı Bahriye Nezareti`

Nazır, bahriyenin genel idaresinden ve Kabine'de yer alan diğer nazırlarla birlikte devletin genel politikasının belirlenmesinden sorumlu tutulmuş; reisi kıdemli subaylar arasından seçilecek olan Kalem-i Mahsus Müdüriyeti ise Nezaret'e gelen tüm evrak, Meclis-i Umumi'ye ve Meclis-i Vükela'ya sunulacak tüm belge ve bilgilerin hazırlanıp düzenlenmesi, daire başkanlarıyla yapılacak toplantı kararlarının kaydı ve muhafazası ile Bahriye Nazırı'nın tüm kişisel ve resmî yazışmalarının idaresiyle görevlendirilmiştir. $\mathrm{Bu}$ müdüriyete bağlı olan birimlerden Tercüme Kalemi, gelen-giden evraka dair her türlü tercüme işinin icrasından sorumlu iken Şifre Kalemi, Nezarete ait tüm şifrelerin anahtarlarını düzenlemek ve saklamak, şifre haberleşmelerini gerçekleştirmek, yazışmaları deşifre etmek ve kodlamakla mükellef tutulmuştur. Nazır veya Kalem-i Mahsus Müdürü tarafından havale edilen her türlü evrakın kaydı, ilgili yerlere dağıtılması ve arşivlerin idaresi Evrak-1 Umumiye Müdüriyeti'nin uhdesine verilmiştir. Muhasebe

\footnotetext{
* Şekil, yazar tarafindan oluşturulmuştur.
} 
Müdüriyeti, donanmanın mali idaresi, dairelerin talepleri doğrultusunda bahriye bütçesinin hazırlanması ve Müdüriyete bağlı olan Bahriye Mutemetliği ve Tahsilat Komisyonu'nun idaresinden sorumlu tutulmuştur. Bahriye Nazırı tarafından havale edilen davaların mevcut yasa ve yönetmeliklere uygun olarak ele alınması hususunda Divan-1 Harb-1 Daimî görevlendirilirken; Bakanlık lehinde veya aleyhindeki tüm davaların takibi Hukuk Müşavirliği’nin sorumluluğuna verilmiştir. ${ }^{63}$

Nizamnamenin ikinci bölümü Nezaret'e bağlı olan dört daireyi oluşturan her bir şubenin vazifelerine ayrılmıştır. Her dairenin bir reis ve reis emri altında çalışan şube müdürlerinin idaresine verildiği bu işleyiş içerisinde evrak işlerinin kısa tutulması ve şube müdürleri ve şubelerde görevli subay ve memurların kendi yetki alanlarındaki meseleleri süratli bir biçimde sonuca kavuşturmalarının defaatle altı çizilmiştir. Bu durum muhtemelen, eski sistemde var olan ve Limpus Paşa'nın şikâyetçi olduğu hantal bürokrasinin yeni sistemde de daire reisleri bazında tekrar etmesini engellemek amacını taşımaktadır. Her bir dairede yer alan şubelerin görevleri ise genel hatlarıyla şu şekilde belirlenmiştir:

Birinci Daire (Erkan-ı Harbiye-i Bahriye): Sekiz şubeden oluşan Bahriye Birinci Dairesi; harp ve manevralara dair planlarla seyr-i sefain ile ilgili programları hazırlamak, yabancı devletlerin bahriye kuvvetleri hakkında incelemelerde bulunmak, bahri harekât ve manevraların tamamlanmasından sonra bunların plan ve kritiğini yayınlamak, bahriye hizmeti için gerekli tüm harita, rehber ve risaleler ile seyr-i sefain kitapları, pusulalar, kronometreler, navigasyon ve ölçme aletlerini temin ve muhafaza etmekle görevlendirilmiştir.

İkinci Daire (Mürettebat): Bahriye İkinci Dairesi, tüm branşlardaki subayların ve deniz askerlerinin girişi, talim ve tedrisi, terfii ve seferberliği ile ilgili mesele ve düzenlemeleri ele almak, Mekteb-i Bahriye, Efrad-1 Cedide Mektebi ile Makineci Çarkları Mektebi'nin idaresini yürütmek, subayların genel ve özel kurslarının idaresini gerçekleştirmek ve tüm

\footnotetext{
${ }^{63}$ BOA, İ.MMS, 183-5, (2 Nisan 1914); RMG, Caird Archive, LIM-162, (2 Nisan 1914).
} 
subay ve sivil memurların kayıtları ve tayinleri ile ilgili işleri yürütmekten sorumlu tutulmuştur.

Üçüncü Daire (Teslihat, Imalat-ı Bahriye ve Ebniye İnsaatı): Tersaneler, havuzlar, poligonlar ve cephaneliklerin idaresi, bina ve rıhtım inşaatı, bahriye binalarında ve filoda mevcut makineler, toplar, kundaklar, tüpler, mayınlar, telsiz telgraf ve elektrik teçhizatına dair işler ile tersane dâhilindeki nakliye ve temizlik işlerinin yürütülmesi görevleri Bahriye Üçüncü Dairesi'nin sorumluluğuna verilmiştir.

Dördüncü Daire (Levazım, Mukavelat ve Muhassasat): Dört şubeden oluşan Bahriye Dördüncü Dairesi, gemilerin ve binaların kömür, yağ, top ve sıhhiye levazımı ile tüm tüketim malzemelerinin tedarikinin sağlanması, subaylar ve deniz askerlerinin maaşları, ödenekleri ve emekli aylıkları ile her çeşit harcırah hakkındaki tüm işlerin idaresi ve inşaat, filo ve binalara ait tüm mukavelenameler ile tahlis edilecek veya satılacak gemiler ve malzemelere dair mukavelenamelerle ilgili işleri yürütmekle görevlendirilmiştir.

Görüleceği üzere Amiral Limpus'un hizmet döneminde bahriye idaresine ait en önemli görevler bu dört daire arasında paylaştırılmış ve Nizamname'de birbirleriyle iş birliği içinde çalışmalarının önemi vurgulanmıştır. Ayrı bir birim olarak teşkil edilen Sıhhiye Müfettişliği ise, bütün sağlık subay, sivil memur ve askerlerinin kayıt, kabul, imtihan ve yetiştirilmesi ile filodaki gemiler, hastaneler ve bahriyeye ait mahallerin teftişinden sorumlu tutulmuş ve Merkez Hastanesi ile Muayene-i Tıbbiye Komisyonu, bu müfettişliğe bağlı hale getirilmiştir. Bu düzenlemelerin yanı sıra Teşkilat Nizamnamesi'nde yer verilen bir diğer değişiklik de tümü İstanbul Liman Riyaseti'ne bağlı olan Osmanlı limanlarının dört daireye ayrılması ve Haliç Dersaadet, Bahr-i Ahmer ve Basra Komodorlukları'nın teşkil edilmesidir. ${ }^{64}$ Cemal Paşa, bu revizyonun kaçakçılığın önlenmesi ve liman başkanlıklarının denetim altına alınması amacıyla gerçekleştirildiğini belirtmiştir. ${ }^{65}$ Aşağıdaki diyagram bu düzenlemeyi ifade etmektedir:

\footnotetext{
${ }^{64}$ BOA, I.MMS, 183-5, (2 Nisan 1914); RMG, Caird Archive, LIM-162, (2 Nisan 1914).

${ }^{65}$ Cemal Paşa, Hattralar, s. 110-111.
} 


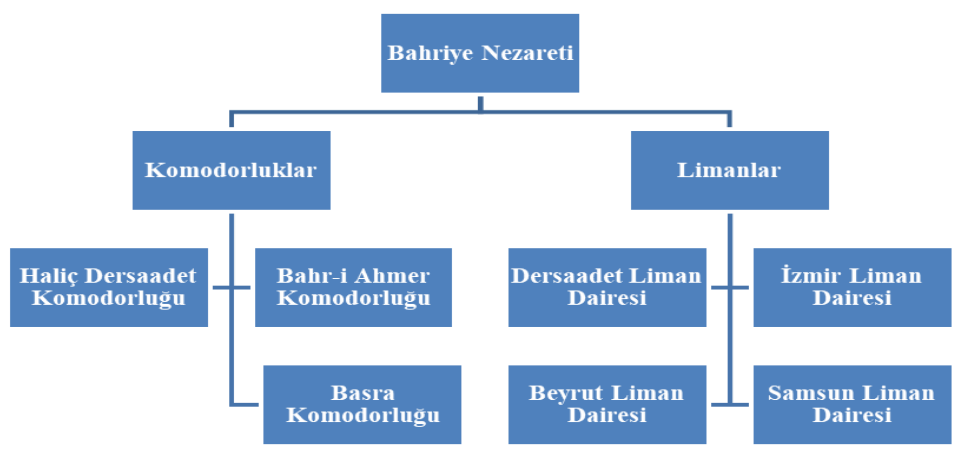

Şekil 2. Bahriye Nezareti'ne Bağlı Liman Merkezleri ve Komodorluklar ${ }^{\star \star}$

Bu düzenlemeye göre; Gemiler, Haliç Umuru, İnzibat ve Merkez Sefinesi olmak üzere dört şubeden oluşan Haliç Dersaadet Komodorluğu, depo gemileri, römorkörler, sac algarinalar, sac maçunalar, tarak dubaları, prizmanlar, kömür mavnaları, su dubaları, yağ dubaları, erzak mavnaları, stimbotlar, filikalar, gemi tekneleri, nöbet kulübeleri ve dalgıç filikaları gibi gemilere dair işleri yürütmekten ve Haliç’teki gemi trafiğinin düzenlenmesinden sorumlu tutulmuştur. Merkezi Hudeyde'de olan Bahr-i Ahmer Komodorluğu, Yemen ve Hicaz Vilayetleriyle Asır Sancağ1 kıyılarında; Basra Komodorluğu ise Basra Körfezi kıyıları ile Şattü’l-Arab, Dicle ve Firat nehirlerinde bulunan sahillerde kaçakçıllğın önlenmesi ve güvenliğin sağlanması görevlerini yürütecektir. Her iki komodorluğun temel görevi gemi hareketliliği hususunda Bahriye Nezareti'ni düzenli olarak bilgilendirmektir. Ayrıca bu birimlerde biri sahil muhafaza ve kaçakçılık işlemleri ve diğeri limanlar olmak üzere iki şube bulunacaktı. Akdeniz ve Karadeniz'de bulunan tüm limanların dört büyük daireye ayrılmasıyla oluşturulan yeni liman başkanlıkları ise, kendilerine bağlı limanların iyi bir çalışma düzenine sahip olması ve gelirlerinin arttırılmasından özel olarak sorumlu tutulmuştur. Yeni düzenlemeye göre; Dersaadet Liman Dairesi, Boğazlar, Marmara'nın tamamı ve Karadeniz'in Rumeli sahilinden Bulgar

${ }^{\star \star}$ Şekil, yazar tarafından oluşturulmuştur. 
sınırına kadar ve Anadolu sahilinden Zonguldak'a kadar uzanan sahillerde bulunan limanların idaresini gerçekleştirecek; Çanakkale Boğazı haricinde ve Adalar Denizi'nde Rumeli sahilinden son sınıra kadar ve Anadolu sahilinden Alaiye'ye kadar olan limanlar İzmir Liman Dairesi'nin sorumluluğuna verilecekti. Beyrut Liman Dairesi'nin yetki sahası Alaiye hariç olmak üzere Beriyyetüşşam sahilinde bulunan bütün limanlar olarak belirlenirken Zonguldak'tan Batum'a kadar Anadolu sahilinde bulunan bütün limanlar, Samsun Liman Dairesi'nin idaresinde olacakt1. ${ }^{66}$

Yapılan yeni düzenlemeyle Bahriye Nezareti, Limpus Paşa'nın 14 Eylül 1912'de hazırladığı rapora paralel olarak İngiliz Bahriyesi teşkilat yapısına benzer şekilde dört daire, üç müdüriyet, Divan-1 Harb-i Daimi, Hukuk Müşavirliği ve Sihhiye Müfettişliği'nden oluşan yeni bir idari mekanizmaya kavuşturulmuştur. Cemal Paşa, Teşkilat Nizamnamesi'nin yürürlüğe konmasını müteakip bahriyede görevli subayların donanmada, sahil muhafaza gemilerinde ve liman reisliklerinde görevli olmak üzere üç sınıfa ayrılmasına dair bir düzenleme planladığını ifade etmiştir. Buna göre bu subaylardan donanmada görevli olup yetersiz bulunanlar sahil muhafaza gemilerine, sahil muhafaza gemilerinde görevini iyi icra edemeyenler liman reisliklerine gönderilecek ve liman reisliklerinde liyakatini ispat edemeyenler emekliye sevk edilecekti. Ancak bu düzenleme Cihan Harbi'nin patlak vermesi nedeniyle hayata geçirilememiştir. ${ }^{67}$

\section{3. İngiliz Danışma Heyeti'nin Terfi ve Taltifleri}

14 Aralık 1913'te Bahriye Nezareti'nden Sadaret'e bir yazı gönderilerek Amiral Limpus ve heyetini oluşturan subaylara hizmetlerindeki gayret ve yararlılıklarından ötürü nişan verilmesi teklif edilmiş; ${ }^{68} 17$ Aralık 1913'te yayınlanan irade ile Umur-1 Bahriye Müşaviri Amiral Limpus Paşa'ya birinci rütbeden Mecidiye Nişanı; Fabrikalar Müdürü Kalyon Çarhcısı Blake Bey, Umur-1 Bahriye Müşavirliği Erkan-1 Harbiye Reisi Firkateyn Kaptanı Asby Bey ve Sivil Mühendis Macfarlane Bey'e üçüncü rütbeden Osmaniye nişanı; Umur-1 Bahriye Müşaviri Kâtibi Stack Bey, Korvet Kaptanı Hallifax Bey ve Korvet Çarhcısı Moore Bey’e üçüncü rütbeden

\footnotetext{
${ }^{66}$ BOA, İ.MMS, 183-5, (2 Nisan 1914); RMG, Caird Archive, LIM-162, (2 Nisan 1914).

${ }^{67}$ Cemal Paşa, Hattralar, s. 11.

${ }^{68}$ BOA, İ.TAL, 488-33 (14 Aralık 1913).
} 
Stratejik İş Birliği ve Askerî Danışmanlık Kapsamında

Osmanlı Donanmasinda Amiral Limpus Misyonu (1912-1914)

Mecidiye Nişanı; Korvet Kaptanı Elliot Bey ve Fabrikalar Müdürü Muavini Page Bey'e dördüncü rütbeden Osmaniye nişanı verilmesine karar verilmiştir. ${ }^{69}$

30 Nisan 1914'te görev süresi sona erecek olan Limpus Paşa'nın mukavelename müddeti 9 Nisan 1914 tarihinde yayınlanan irade ile 30 Nisan 1915'e kadar bir sene daha uzatılmıştır. ${ }^{70}$ Bahriye Nazırı Cemal Paşa, Limpus Paşa'ya gönderdiği yazı ile Limpus'un hizmet dönemi boyunca gösterdiği başarı ve gayretten dolayı Bahriye Dairesi'nin minnettarlığını ifade etmiş ve görev süresinin uzatılması hususundaki memnuniyeti dile getirmiştir. ${ }^{71}$ Cemal Paşa, 21 Nisan 1914'de Londra Sefareti'ne bir mektup göndererek Limpus Paşa'nın heyetindeki beş İngiliz subayın kontratlarının tecdid edildiğini bildirmiş, $;^{72} 2$ Mayıs 1914'te İngiltere Hariciye Nezareti Osmanlı Hükümeti'ne İngiliz subayların Osmanlı donanması hizmetindeki görevlerine devam etmeleri yönünde gerekli olan iznin verildiğini beyan etmiştir. $^{73}$

27 Mayıs 1914'te ise Bahriye Nezareti, Limpus Paşa ile yapılan mukavelenamenin altıncı maddesine atıf yaparak Limpus ve ekibinin Osmanlı donanmasındaki başarılı hizmet dönemleri dikkate alınarak maaşlarında artış yapılmaksızın rütbelerinin birer derece terfi ettirilmesini önermiştir. ${ }^{74} 28$ Mayıs 1914'te yayınlanan bir irade ile Amiral Limpus Paşa'nın rütbesi ferik amiralliğe, Asby Bey'in rütbesi kalyon kaptanlı̆̆ına, Elliot Bey ve Hallifax Bey'in rütbesi firkateyn kaptanlığına, Moore Bey'in rütbesi firkateyn çarhcıllğına ve korvet kâtibi Stack Bey'in rütbesi firkateyn kâtipliğine yükseltilmiştir. ${ }^{75}$

\section{Sonuç}

İngiltere Bahriye Nazırı Winston Churchill'in bizzat seçtiği Amiral Arthur Limpus, 25 Mayıs 1912'de Osmanlı donanmasının umur-1 bahriye

\footnotetext{
${ }^{69}$ BOA, İ.TAL, 488-33 (17 Aralık 1913).

${ }^{70}$ BOA, İ.BH, 12-75 (9 Nisan 1914); Cemal Paşa'dan Limpus'a, RMG, Caird Archive, LIM-100, (7 Nisan 1914).

${ }^{71}$ Cemal Paşa'dan Limpus'a, RMG, Caird Archive, LIM-100, (15 Nisan 1914).

${ }^{72}$ BOA, HR, SFR.3, 706-10 (21 Nisan 1914).

${ }^{73}$ BOA, HR, SFR.3, 706-10 (2 May1s 1914).

${ }^{74}$ BOA, İ.BH, 13-10, (27 May1s 1914).

${ }^{75}$ BOA, İ.BH, 13-10 (28 May1s 1914).
} 
müşaviri ve donanma kumandanı unvanıyla görevine başlamıştır. Churchill, 1914'ten önce, Hariciye Nazırı Edward Grey'in aksine Osmanlı İmparatorluğu'nun eninde sonunda parçalanacağı ve İngiltere'nin Doğu politikasını bu kaçınılmaz sona göre belirlemesi gerektiği düşüncesi ekseninde bir siyaset benimsememiştir. İttihat ve Terakki Cemiyeti üst yönetiminin Almanya ile yakınlaşması ve İstanbul'da giderek artan Alman nüfuzu karşısında özellikle 1912'den sonra bu etkiyi kırmaya yönelik bir politika takip etmeye başlamıştır. İngiliz bahriye misyonlarının Osmanlı donanmasında görevlendirilmesi, kendisinin Limpus gibi seçkin bir amirali bu görev için bizzat seçmesi, Limpus'un görevi müddetince Churchill'e gönderdiği raporlar ve Osmanlı bahriyesi bünyesinde gerçekleştirilecek teknik modernizasyonda Limpus'un, İngiltere menşeli firmalarla çalışılmasına yönelik gayretlerinin göstereceği üzere Osmanlı bahriyesinin reorganizasyonu için gönderilen Amiral Limpus misyonu, Churchill'e ait bu politikanın Osmanlı Hükümeti'ne benimsetilmesi için kullanılan en etkin vasıtalardan birini teşkil etmiştir.

Görevlendirme sürecinde Limpus'un gerek selefleri Gamble ve Williams'la yaptığı görüşmeler gerekse Osmanlı İmparatorluğu Londra Sefareti'nin Osmanlı Bahriye Nezareti'yle yürüttüğü müzakereler, Osmanlı bahriyesinde görevlendirilen İngiliz subayların yetki alanlarının belirlenmesi hususunda net bir tavır gösterilmediğini ve bu durum sebebiyle subayların hizmet dönemleri esnasında birtakım bürokratik engellerle karşılaştıklarını ortaya çıkarmıştır. Londra Sefiri Tevfik Paşa'nın Osmanlı Hükümeti nezdinde yaptığı girişimler sonucunda Amiral Limpus'un da aynı problemlerle karşılaşmasının önüne geçilmiş; görev tanımı ve çalışma şartlarının ortaya konduğu mukavelenamede İngiliz Bahriyesi ve İngiltere Hariciye Nezareti'nin doğrudan müdahalesiyle öngörülen değişiklikler, Bahriye Nezareti tarafından itiraz edilmeksizin kabul edilmiştir. Bahriye Nazırı Hurşid Paşa'nın Limpus yeni müşavir olarak seçildikten sonra halen İstanbul'da bulunan Williams'ı yeni amiral gelmeden göndermeye çalışması ve Williams ile Limpus'un karşılaşmalarından endişe duyması yabancı basında da yankı bulmuş ve Londra Sefareti tarafından büyük bir tepkiyle karşılanmıştır. Hurşid Paşa, Bahriye Nezareti'nin bu tavrını Limpus'un ekibinin tamamen yeni isimlerden oluşmasını sağlamak olarak açıklamıştır ki bu durum Williams misyonunun Bahriye Nezareti bünyesinde başarısız bulunduğu ve Williams'ın ekibine dâhil olan hiçbir 
Stratejik İş Birliği ve Askerî Danışmanlık Kapsamında

Osmanlı Donanmasında Amiral Limpus Misyonu (1912-1914)

subayın yeni ekip içerisinde istenmediğini ortaya koymuştur. Bunun yanı sıra Amiral Limpus'un mukavelenamesine ilişkin müzakereler devam ederken Bahriye Nazırı Hurşid Paşa'nın sonradan verilmesi kararlaştırılmış olan görev talimatnamesini aceleci bir tavırla Amiral Limpus'a iletmeye çalışması, kendi yetki alanının boyutlarını Amirale açık bir biçimde göstermek isteğini düşündürmektedir. Bahriye Nezareti tarafından "fen müşaviri” olarak görevlendirilmek istenen İngiliz amirallerin hangi hususlarda ve ne ölçüde hareket edeceğini ayrıntılı bir biçimde ortaya koyan bu talimatname, daha yeni amiral göreve başlamadan selefiyle yaşanan problemlerin bahriye nazırı bünyesinde devam ettiği izlenimini vermekte ve nazırlar ile müşavirler arasında yetkilendirilme bakımından süregelen bir ihtilafın mevcudiyetini kanıtlamaktadır.

Amiral Limpus, hizmet döneminin başından itibaren Bahriyede mevcut problemler ve çözüm önerileri hususunda Bahriye Nezareti'ni düzenli olarak bilgilendirmiştir. Mukavelenamesinin on beşinci maddesi gereği Trablusgarp ve Balkan Savaşları esnasında filoda aktif görev alamamış; bu nedenle hizmet döneminin büyük bölümünde teşkilatın yeniden yapılanması, zabitan ve efradın eğitimi, Reşadiye ile Sultan Osman-ı Evvel dretnotlarının İngiltere'deki inşa süreci ve İzmit Körfezi’nde inşa edilecek yeni deniz üssü projesi üzerinde yoğunlaşmıştır. Hazırladığı raporlar incelendiğinde Osmanlı bahriyesinin reorganizasyonu amacının önündeki en büyük engel olarak bahriyeye ayrılan bütçenin ihtiyaç duyulandan çok daha az olmasını göstermiş ve raporlarında bütçeye ilişkin çeşitli önerilerde bulunmuştur. Ayrıca bu hususta Osmanlı İmparatorluğu'na Almanya'nın yardımcı olmasına engel olunması ve İngiltere'nin desteğinin sağlanması hususunda Churchill'i bilgilendirmiştir. Bunun haricinde bahriye nazırlarının sıklıkla değiştirilmesinin bahriye idari mekanizması üzerinde son derece olumsuz bir etkiyi haiz olduğunu belirterek yeni atanan nazırların mevcut sisteme ve personelin de yeni nazırın idari politikalarına adaptasyon sürecinin büyük zaman kaybına yol açtığını vurgulamıştır. Teşkilat yapısının yeniden düzenlenmesi için sunduğu öneriler Williams Paşa'nın da şikâyetçi olduğu Bahriye Müsteşarı Rüstem Paşa'nın muhalefeti nedeniyle hayata geçirilememiş; Cemal Paşa'nın Bahriye Nazırı olarak tayini ve bunu müteakip Rüstem Paşa'nın emekli edilmesi sayesinde yeni idari yapının ortaya konduğu Bahriye Nezareti Teşkilat Nizamnamesi 2 Nisan 1914'te yürürlüğe konmuştur. Görevlerini istifa ederek terk eden 
Gamble ve Williams Paşaların aksine Osmanlı Hükümeti ve Bahriye Nezareti ile kurduğu pozitif diyalog ve başarılı geçen hizmet dönemi neticesinde görev süresi bir yıl daha uzatılmış, rütbesi ferik amiralliğe yükseltilmiş ve birinci rütbeden Mecidiye Nişanı ile ödüllendirilmiştir. Tersane-i Amire'nin mevcut durumu ile işlevsiz olması sebebiyle İzmit'te yeni bir deniz üssünün inşasına yönelik projesi uygun bulunmuş; bu hususta ArmstrongVickers firmaları ile Osmanlı Hükümeti arasında bir anlaşma yapılması için büyük çaba sarfetmiş ancak patlak veren Birinci Dünya Savaşı nedeniyle Osmanlı Hükümeti'ndeki görevi Eylül 1914'te sona ererek Malta'ya gönderilmiştir. ${ }^{76}$

\section{Summary}

In 1908, when the constitutional monarchy in the Ottoman Empire was declared, the only ships which were in seaworthy condition and fit for active service in the Ottoman Navy were the armoured vessels Mesudiye, Asar$\imath$ Tevfik, Feth-i Bülend, Avnillah, and Muin-i Zafer, the $2^{\text {nd }}$ class protected cruisers Mecidiye and Hamidiye, the torpedo vessels Peleng-i Derya, Berk-i Satvet and Peyk-i Şevket and the torpedo boats Akhisar, Alpagot, Hamidabad, Sultanhisar, Demirhisar, Sivrihisar, Ankara, Urfa, Antalya, Tokat, Draç, Kütahya, and Musul. The docks and factories in the Imperial Naval Arsenal in Istanbul were useless due to negligence and non-use and the manufacturing and construction activities were suspended. The Ottoman Government desired to gain superiority in the naval race with the Greek navy in the Aegean Sea and for this purpose three British naval missions were commissioned in the Ottoman Navy until the beginning of World War I. Due to the resignation of

\footnotetext{
${ }^{76}$ Amiral Limpus, İzmit Körfezi’nde yeni bir deniz üssünün inşası amacıyla gerekli planlamaların yapılması, proje taslaklarının oluşturulması ve İngiliz ArmstrongVickers grubu ve Osmanlı Hükümeti arasında yapılan müzakerelerin yürütülmesi görevlerini de yerine getirmiştir. Ayrıca Reşadiye ve Sultan Osman-ı Evvel dretnotlarına Ingiliz Hükümeti tarafından 1914'te el konulması ve ardından Goeben ve Breslau isimli Alman gemilerinin Osmanlı Hükümeti tarafından satın alınması ile başlayan süreçte, Osmanlı tarafsızlığının korunması ve Osmanlı İmparatorluğu'nun Birinci Dünya Savaşı'na Almanya yanında girmesinin engellenmesi amacıyla İngiliz Hükümeti nezdinde yürütülen müzakerelerde aktif rol oynamıştır. Bu hususlarda hazırladığımız bölümlere kelime sınırlanması sebebiyle burada yer veremedik ancak bir diğer makale halinde yakın zamanda okuyucunun ilgisine sunulacaktır.
} 
Stratejik İş Birliği ve Askerî Danışmanlık Kapsamında

Osmanlı Donanmasında Amiral Limpus Misyonu (1912-1914)

Admiral Douglas Gamble (1909-1910) and Admiral Hugh Williams (19101911), who worked as technical advisers who developed projects on the strengthening of the fleet and the training of officers and soldiers, the Ottoman Government applied to Britain again in January 1912. Admiral Arthur Henry Limpus, who was selected by the First Lord of the Admiralty Winston Churchill, started his duty as naval adviser and commander of the Navy in the Ottoman Ministry of Navy on 25 May 1912. The correspondence that Admiral Limpus exchanged with his predecessors during his assignment process showed that Gamble and Williams had some problems during their term of office as their scope of authority was not clearly determined in the Ottoman navy. Therefore, the statement that Limpus would be assigned as a "technical adviser" in the first article of the contract prepared by the Ottoman Ministry of Navy was disapproved by the British Admiralty and the Ministry of Foreign Affairs, and this title was changed to "naval adviser". As a result of the further negotiations, Admiral Limpus was assigned to the Ottoman Navy between 30 April 1912 and 30 April 1914 with an annual salary of 3000 sterling. In May 1912, when Limpus started his assignment in the Ottoman Navy, the Italo-Turkish War was continuing and it ended in October 1912. From October 1912 to August 1913, the Ottoman Government was at war with the Balkan States. According to the $15^{\text {th }}$ article of Limpus' contract, the British naval mission would not be employed in the fleet when the Ottoman Empire was at war with another state, and for this reason; Limpus and other British officers did not take an active role in the fleet during this period and were assigned to non-war duties and education-related issues. Since the beginning of the period of his service, Limpus Pasha regularly informed the Ministry of Navy about the existing problems and suggestions for solutions. He determined the naval policy of the Ottoman Empire as establishing a fleet equivalent to the Austrian navy if sufficient resources could be allocated from the budget. Limpus frequently stated in his reports that the budget allocated to the navy was much less than needed and he made suggestions regarding the required budget for the successful completion of the targeted projects. Another problem was the frequent change of the Ministers, which had an extremely negative impact on the administrative mechanism of the Navy. Limpus emphasized that the adaptation process of the newly appointed ministers to the existing system and the personnel to the administrative policies of the new minister caused a great waste of time. In parallel with his 
reports regarding the Ministry's organizational structure, Regulation for the Admiralty Organization was constituted on 2 April 1914. With the new regulation, the Ministry of Navy had acquired a new administrative mechanism consisting of four departments, three bureaux, Medical Inspector General, Permanent Court Martial, and Legal Adviser, similar to the organizational structure of the British Admiralty. Limpus Pasha also organized courses for the officers and soldiers in the fields of navigation, artillery, engineering, and torpedo and ensured that the effectiveness of the success of officers in these courses regarding their promotion and their professional career in the navy was kept at a high level. Due to the unfavourable state of the Imperial Naval Arsenal especially for the dreadnoughts, which were under construction in Britain, the project for the construction of a new naval base in the Gulf of Izmit, first developed by Admiral Gamble and later advanced by Admiral Limpus, was approved by the Ministry of Navy. Although Limpus Pasha made great efforts to make an agreement between the Armstrong-Vickers companies and the Ottoman Government for this purpose, he was sent to Malta after his service in the Ottoman Navy was ended in September 1914 due to the outbreak of World War I.

\section{Çatışma Beyanı:}

Makalenin ile ilgili herhangi bir kurum, kurulus,, kişi ile çıkar çatısması bulunmamaktadir.

\section{Destek Beyani:}

Teşekkür Beyanı: Bu çalısmanın önemli bir bölümü Türkiye Bilimsel ve Teknolojik Araştırma Kurumu (TÜBİTAK), Bilim İnsan Destekleme Daire Başkanlığı tarafindan verilen 2219-Yurt Dışı Doktora Sonrası Araştırma Bursu ile gerçekleştirilmiştir (Araştırma Proje No. 1059B191800794). 


\section{Kaynakça}

Arşiv Kaynakları

İngiliz Ulusal Denizcilik Müzesi Caird Arşivi (RGM)

Limpus Evrakı (LIM)

İngiliz Ulusal Arşivi (TNA)

İngiliz Bahriyesi İstihbarat Belgeleri (ADM)

Başbakanlık Osmanlı Arşivi (BOA)

Bâb-1 Ali Evrak Odası (BEO), Bâb-1 Âsafî Divan-1 Hümayun Mukavele (A.DVN.MKL), Hariciye Nezareti İare (HR.ID), Hariciye Nezareti Londra Sefareti (HR.SFR.3), İrade Bahriye (İ.BH), İrade Meclis-i Mahsus (İ.MMS), İrade Taltifat (İ.TAL), Sadaret Mektubî Kalemi Mühimme (A.MKT.MHM)

\section{Kitaplar}

CEMAL PAŞA, Hatralar, (Yay. Haz. Alpay Kabacalı), Türkiye İş Bankası Kültür Yayınları, İstanbul, 2006.

\section{Makaleler}

BEDİRHAN, Y., ATABEY, F., "Osmanlı Bahriyesi'nde Yabancı Danışmanlar (18081918), Turkish Studies, 2013, 8-5, 127-139.

ÇOKER, F., "Osmanlı Bahriyesinde İngiliz Islah Heyetleri (1839-1914)”, Bahriyemizin Yakın Tarihinden Kesitler, Deniz Kuvvetleri Komutanlığı, Ankara, 1994.

ROONEY, C. B., "The International Significance of British Naval Missions to the Ottoman Empire, 1908-14”, Middle Eastern Studies, 1998, 34-1, 1-29.

Gazeteler

The Times, 13 Nisan 1912, 15 Nisan 1912.

The Levant Herald, 12 Haziran 1912.

Tanin, 18 Mayis 1912. 